The Determinants of CSR Disclosure Quantity and Quality: Evidence from Non-Financial Listed Firms in Saudi Arabia

\author{
Khaleed Alotaibi* \\ PhD Candidate \\ Plymouth Business School, Plymouth University \\ khaleed.alotaibi@plymouth.ac.uk \\ Shaqra University, Saudi Arabia \\ kalotaibi@su.su.edu.sa \\ Khaled Hussainey* \\ Professor of Accounting \\ Plymouth Business School, Plymouth University \\ Khaled.Hussainey@plymouth.ac.uk
}




\title{
Determinants of CSR Disclosure Quantity and Quality: Evidence from Non-Financial Listed Firms in Saudi Arabia
}

\begin{abstract}
:
The purpose of this study is to examine the practice of Corporate Social Responsibility (CSR) Disclosure in a Saudi Arabian context. This study has two particular objectives. Firstly, it aims to measure the level of CSR disclosure quantity and quality. Secondly, it aims to investigate the determinants of CSR disclosure quantity and quality in a Saudi Arabian context. The study examined a sample of 171 observations from Saudi non-financial listed firms covering the period of 2013-2014. In addition, it develops CSR disclosure indices to measure the level of quantity and quality of CSR disclosure. The study found that Saudi Arabian firms provided higher levels of CSR disclosure quantity; however, the quality of is the disclosure was relatively low. In addition, the study found that CSR disclosure quantity was positively associated with board size and the size of audit committee. However, it is negatively associated with percentage of governmental ownership, and size of remuneration committee. On the other hand, the quality of CSR disclosure was positively associated with the board size and the percentage of managerial ownership. However, the study found a negative association with the percentage of independent directors. The results suggest that Saudi Arabia provides higher levels of CSR disclosure quantity with a lower of CSR disclosure quality. In addition, the levels of CSR disclosure quantity and quality have different drivers.
\end{abstract}

Keywords: Corporate Social Responsibility (CSR) Disclosure, Saudi Arabia. 


\section{INTRODUCTION}

This study aims to address two objectives. Firstly, it aims to measures the level of CSR disclosure quantity and quality in Saudi Arabian non-financial firms. Secondly, it aims to identify the factors that may drive managers of Saudi Arabian firms to provide different levels of CSR disclosure quantity and quality.

Corporate Social Responsibility (CSR) disclosure is considered the main communication tool for stakeholders of firms regarding CSR activities (Belal \& Cooper, 2011). The last few decades have witnessed an increased interest in CSR (Aribi, 2009) .Today, a number of stakeholders are demanding social and environmental information, such as information related to the environment, society and pollution damage. This information would help companies to justify their activities to a wide range of stakeholders by providing a higher level of CSR disclosure regarding a number of social and environmental issues, beyond simply the economic environment of the firm (Daub, 2007).

The CSR is considered a fundamental tool used by companies for public relations to communicate and create a mutual understanding, managing potential conflicts and providing legitimacy to the stakeholders and society as a whole (Golob \& Bartlett, 2007). It is evidenced that this form of voluntary disclosure has attracted wider interest in research studies; however, earlier research highlights some issues relating to the CSR disclosure level of the company's annual report in developed countries (e.g., Saudi Arabia).

Currently, the CSR is highly recognised across developed countries, it is not an additional policy option which firms apply in providing disclosure. ; i.e., companies do not consider the CSR disclosure to be a luxury nor do they feel that by providing disclosure it somehow enhances their goodwill when dealing with society. However, firms today consider the CSR to be a main part of their policies and strategies. Whilst, firms in developing countries are still in the early stages of adopting the CSR into their strategies and policies as well as integrating it into the firm's activities. This study - aims to explore the level of CSR disclosure quantity and quality in a Saudi Arabia context and will aim to identify the determinants of CSR disclosure quantity and quality within Saudi Arabian non-financial listed firms.

Saudi Arabia is considered as a member of the Gulf Cooperation Council (GCC). It hosts many industries such as petrochemicals, - customer services, and cement, refining and healthcare. Recently, firms in Saudi Arabia have started to pay much more attention to the CSR activities in their annual reports. Furthermore, the Saudi Arabia governance code has 
considered the disclosure of CSR activities to be part of the required disclosure that should be provided by firms. This is in turn provides value relevant information to different stakeholders and contributes to the society as a whole. However, there is no guidance available in the theoretical and practical frameworks that have examined this phenomenon, particularly within the Saudi Arabian context.

Further, there are several motivations in examining the level of CSR disclosure quantity and quality and in identifying the determinants of CSR disclosure in a Saudi Arabian context. Firstly, Saudi Arabia established a corporate governance code in 2007; the code was significantly affected by the country's Islamic principles that led to an introduction of Islamic characteristics appearing in the governance code. (Albassam, 2014).

Secondly, Saudi Arabia's economy is considered huge and it has vast economic prominence in the Arab region. In 2010, it represented 25\% of the total Arab Gross Domestic Product (GDP) and $44 \%$ of the total Arab market capitalisation (Albassam, 2014; Alshehri \& Solomon, 2012). Furthermore, Saudi Arabia contains a quarter of the world's oil reserves and is considered to be one of the largest oil producers in OPEC. Oil production in 2010 was about $31 \%$ of the total OPEC production (Albassam, 2014; Habbash et, al. 2015).

Thirdly, the ownership structure of firms listed in Saudi Arabia is family and stateconcentrated. This means that family owned firms represent more than $70 \%$ of the listed firms. In addition, the Saudi government owns more than $30 \%$ of the Saudi Arabian firms (Albassam, 2014; Baydoun, et al. 2013; ROSC, 2009; Habbash et, al. 2015).

Finally, to the best of our knowledge, only three studies have previously examined the drivers of voluntary disclosure in Saudi Arabia; namely, Al-Janadi et al. (2013) and Alsaeed (2006) and Habbash et al. (2015). This study adds major contributions to research on CSR disclosure as the voluntary disclosure in Saudi Arabia as follows: Firstly, we have used data from more wide-ranging and more recently listed non-financial firms covering the period of 2013-2014. Whereas Al Janadi et al. (2013), covered the period 2002-2003, Alsaeed (2006), covered the period 2006-2007 and Habbash et al. (2015), covered the period 2007-2011. Secondly, AlJanadi et al. (2013) examined the impact of corporate governance on voluntary disclosure, whereas Alsaeed (2006), examined the impact of firm characteristics on voluntary disclosure. While Habbash et al. (2015), examined the determinants of voluntary disclosure in Saudi Arabia. Furthermore, there is limited research in this particular area of investigating CSR disclosure in the Saudi firms listed; namely, Abbas et al. (2012) examined the nature of CSR 
and how this evolving concept took root in an emerging oil- rich country like Saudi Arabia. In addition, Mandurah et al. (2012), examined the CSR among Saudi Arabian firms and Nalband et al. (2013), examined the CSR perception, practices and performance of listed companies of Saudi Arabia. Consequently, all of them used a qualitative method to investigate the CSR disclosure in terms of knowledge, awareness and understanding the managers had towards the CSR.

Our study investigates CSR disclosure level quantity and quality and identifies the determinants of the CSR disclosure quantity and quality of non-financial firms listed in Saudi Arabia. This study covers 171 observations carried out in various firms during the period of 2013-2014. All of these factors motivate us to examine the determinants of CSR disclosure in Saudi Arabia. In addition, it is argued that the area of voluntary disclosure (in general) is still under-researched (Habbash et al., 2015).

Saudi Arabia provides a unique country context within which the CSR disclosure can be analysed. This is because of the following reasons. Firstly, Saudi Arabia is a country with an emerging economy. It has different religious, social and political systems as well as traditions, which differ from developed countries. For instance, the Islamic principles in Saudi Arabia affect the daily life, business, law, economics and political aspects of the whole of Saudi society. Secondly, Saudi Arabia enhanced its corporate governance code in 2012; this enhanced code requires companies to disclose their CSR activities in their annual reports. In addition, this code is affected by the country's Islamic principles, which resulted in the introduction of Islamic governance characteristics (Albassam, 2014). This is in turn may affect the level of CSR disclosures of Saudi Arabian firms.

However, there is limited research that examines the practice of CSR disclosure in developing countries as stated in the annual report by Hussainey et al., 2011; Nalband et al., (2013). Existing research on the determinants of CSR disclosure in developing countries is rare, particularly in Saudi Arabia. Furthermore, in Saudi Arabia there is a lack of concern among regulatory bodies regarding CSR disclosure; this may be because they feel that CSR disclosure is not relevant for investors. Therefore, this paper aims to examine the practice of CSR in a developing country, particularly Saudi Arabia.

This study develops two disclosure indices, one for measuring the level of CSR disclosure quantity and the other for measuring the level of CSR disclosure quality. It uses samples from non-financial firms listed in Saudi Arabia over the period of 2013-2014. This study found 
that Saudi Arabian firms provide higher levels of CSR disclosure quantity; however, the quality of this disclosure is relatively low. In addition, the CSR disclosure quantity is positively (negatively) associated with board size, (that is the percentage of governmental ownership), the size of the audit committee and (size of remuneration committee). On the other hand, the quality of CSR disclosure is positively (negatively) associated with board size, (the percentage of independent directors) and by percentage of managerial ownership.

This study offers the following contributions to the CSR disclosure literature in general and corporate governance in particular. Firstly, it introduces a new measure of CSR disclosure quantity based on the previous study carried out by $\mathrm{Ng}, 1995$; Hackston \& Milne (1996). This measure will take the Islamic culture of Saudi Arabia into account and adds some additional factors to the measure of CSR disclosure quantity that are consistent with the Saudi environmental, such as The existence of charitable societies that support activities like the memorisation of The Holy Quran. (details are included in appendix 1). Secondly, this is the first study to measure the CSR disclosure quality based on the qualitative characteristics of financial information. Thirdly, to the best of our knowledge, this is the first study to examine the determinants of both the quantity and quality of the CSR disclosure in a Saudi Arabian context, as one of the developing countries. Furthermore, it offers evidence that CSR disclosure quantity is not a proxy of CSR disclosure quality.

The remainder of this paper is structured as follows. Section 2 provides the theoretical framework; it draws on the definitions of CSR disclosure quantity and quality and theories. Section 3 discusses the research literature and hypothesis development. Section 4 presents the research design, Section 5 reports the results and finally, section 6 presents a conclusion.

\section{THEORETICAL FRAMEWORK: CSR DISCLOSURE, THEORY, LITERATURE AND HYPOTHESIS DEVELOPMENT}

This section provides an overview of the CSR disclosure quantity and quality, and introduces theories that explain the need for CSR disclosure and summarises the literature and presents the research hypothesis.

\section{2-1 CSR disclosure: quantity and quality}

CSR is one of the new accounting concepts, that have not only economic and legal responsibilities but also social and moral responsibilities to other parties concerned (stakeholders), such as customers, employees, communities, investors, governments, 
suppliers and even competitors (Anwar et al, 2010). CSR can be defined as actions on the part of a firm that appear to further some social good beyond the immediate interests of a firm and beyond legal requirements (McWilliams \& Siegel, 2001). The CSR disclosure is considered a key concept in many fields of research, such as quality of life, quality of food and quality of service. In some cases, there are conflicts regarding the context and subject of the CSR concept (Carroll, 1983). Accordingly, it is argued that disclosure indices combine measures of different dimensions into one single abstract value that has a limited appeal. Galbreath (2010) further states that: "CSR comprises the economic, legal, ethical and discretionary responsibilities firms assume towards their stakeholders".

The concept of quality of the CSR disclosure is a debated issue in existing disclosure literature. From a business perspective, it is defined as 'the extent to which a product or service meets user expectations". According to ISO 9000, it is defined as the degree to which a set of inherent characteristics meet certain requirements. More specifically, the concept of disclosure quality reflects the level of disclosure that meets the user's needs. However, the disclosure quality is still debuted to identify the definition and measurements (Beretta and Bozzolan, 2004; Botosan, 1997; Beest and Braam, 2011; Anis et al., 2012).

\subsection{The Saudi Corporate Governance Code (SCGC)}

It is stated that the Saudi Corporate Governance Code (SCGC) is considered to be a key driver in applying good corporate governance practices across Saudi listed firms (Albassam, 2014). The code contains many parts, for instance, part three of the SCGC emphasises specifically to increase corporate transparency and voluntary disclosure. In addition, this part of the code requires inclusion and classification of some of the variables of the code such as the board size, executive directors, non-executive directors, independent directors, and CEOs. The companies also have to provide information regarding the sizes of their audit and remuneration committees as well as information about the meeting of board of directors. The SCGC seeks to reduce agency conflicts between mangers and shareholders through improving transparency, accountability and responsibility of corporate board of directors (ROSC, 2009; Alshehri and Solomon, 2012). In addition, the code encourages firms to be more socially responsible. Consequently, Article 10 of the code (which covers social responsibility), governs to protect other stakeholders such as local communities, employees and the environment. 


\subsection{Theories}

\subsubsection{Legitimacy and stakeholder theories}

As stated earlier, the legitimacy and stakeholder theories are used to explain the practice of corporate social responsibility; however, the legitimacy theory offers a far superior explanation (Gray, Owen \& Adams, 1996). According to the legitimacy theory, the CSR disclosure aims to legitimise the behaviour of the firm through providing information, which is intended to affect the stakeholders and society's perception about the firms (Hooghiemstra, 2000).

The legitimacy theory is closely related to the stakeholder theory. The demand for CSR disclosure has been driven by the increasing popularity of stakeholders (Boesso \& Kummar, 2007). Overall, companies can provide the social information in their annual reports to enhance the firm's reputation in the eyes of its stakeholders and to satisfy the community's need (Hassan et al., 2010).

\subsubsection{Signalling theory}

The signalling theory suggests that mangers of firms are more likely to disclose more information in order to signal their favourable results (Hassanein \& Hussainey, 2015). Accordingly, firms may use CSR disclosure to signal to their investors that they have favourable results, which in turn enhance their image in the market (Sun, Salama, Hussainey and Habbash, 2010). In addition, the CSR disclosure is a way of signalling to investors and other stakeholders that the company is actively taking part in the CSR activities. Furthermore, by participating in the CSR activities it helps the company to establish a good reputation for reliability in the capital markets.

\subsubsection{Agency theory}

Jensen and Meckling (1976: 308) define the agency relationship as "a contract under which one or more persons (the principals) engage another person (the agent) to perform some service on their behalf, which involves delegating some decision-making authority to the agent". It is concerned with the problems of information asymmetries in markets (Morris, 1987). Agency theory suggests that firms may use a compensation plan or provide voluntary disclosure to reduce the agency costs. The CSR activities require firms to be more accountable to its stakeholders and to the whole of society. This is in turn will divert the attention of shareholders from monitoring earning manipulation to other issues, which in turn 
enhances the share price of the firm. In addition, the CSR activities may help the company to retain superior profits in the market. Consequently, this reduces any agency conflict between management and its shareholders (Sun, et. al., 2010).

\section{3- Hypotheses development and literature}

\section{3-1 Board size}

The agency theory suggests that board size is a potential variable of corporate governance to monitoring management performance (Fama and Jensen, 1983; Allegrini and Greco, 2013). There are debates about the size of a board of directors. Some prior research argues that the board size promotes more effective decision-making and develops information-processing capabilities. While on the other hand, others argue that a larger board can be less participating between members, in order to increases the opportunity for manipulation (Ho \& Williams, 2003). Healy and Palepu (2001) indicated that by nominating a board of directors, who deed on behalf of investors, is an efficient mechanism that affects mangers' voluntary disclosure decisions and controls the agency problem. Ntim et al. (2012a) find that board size is a vital determinant of voluntary corporate disclosure. In the context of the expected impact of board size on CSR disclosure, Halme \& Huse (1997) argued that in a large board, there is a higher probability of a broader range of stakeholders, which indicates that a higher level of environmental attention can be expected (Halme \& Huse, 1997: 142). More specifically, they present a positive and significant association between board size and voluntary corporate disclosure among 169 South African firms. Furthermore, Albassam (2014) shows that, in the Saudi corporate context, the relationship between board size and voluntary corporate disclosure is not well documented. For instance, Al-Moataz and Lakhal (2012) find no significant relationship between board size and corporate governance practices. In addition, other prior research finds a positive relationship between board size and voluntary disclosure (e.g., Laksamana, 2008; Hussainey and Al-Najjar, 2011). Therefore, based on the above discussion, this study hypothesises that:

H 1 a: There is an association between board size and CSR disclosure quantity.

$\mathrm{H} 1 \mathrm{~b}$ : There is an association between board size and CSR disclosure quality. 


\section{3-2 Independent directors}

The agency theory explains the relationship between the principle and agent (Eisenhardt, 1989; Bruton et al., 1997). Forker's (1992) finds a positive association between the percentage of outside directors on the boards and the comprehensiveness of financial disclosure. Furthermore, others research reports the same results (e.g., Arcay and Vazquez, 2005; Cheng and Courtenay, 2006; Boesso and Kumar, 2007; Laksamana, 2008). In addition, Chen and Jaggi (2000) and Gul and Leung (2004) suggest that a higher number of independent directors sitting on a board makes it becomes more effective and consequently this board improves the levels of corporate transparency and disclosure.

On the other hand, further research finds a negative relationship between outside directors sitting on the boards and the levels of voluntary disclosure (e.g., Eng and Mak, 2003; Barako, Hancock and Izan, 2006; Hoitash and Bedard, 2009). Others studies find insignificant associations between the two variables (e.g., Hoe and Wong, 2001; Haniffa and Cooke, 2002).

Rose (2007, pp. 321) suggests that "reported that new regulations, requiring more independent directors, are a major step in improving corporate ethics and social responsibility". Therefore, an increase in the percentage of independent directors on the board encourages companies to deal positively with social pressure and increases the level of CSR disclosure. This research attempts to examine the association between CSR disclosure and board independence in Saudi listed companies. Therefore, the following research hypotheses are developed:

\section{H 2 a: There is an association between independent directors and CSR disclosure quantity.}

H 2 b: There is a relationship between independent directors and CSR disclosure quality.

\section{3-3 Government ownership}

The stakeholder theory suggests that governmental ownership is a key factor that influences on the corporate governance disclosure, particularly, in developing countries like Saudi Arabia, which are profoundly building up on the ownership structure (Shleifer, 1998; Cornett et al., 2010; Al-Moataz and Hussainey, 2012). Eng and Mak (2003) find that agency problems are more likely to increases with ownership size, such as government ownership. In addition, is argued that government ownership normally leads to intervention by the 
government in the running of the firm, which can lead to poor corporate governance practices (e.g., Bolton and Thadden, 1998; Konijn et al., 2011). Eng and Mak (2003) have studied the association between government ownership and voluntary disclosure using a sample of 158 firms listed on the Singapore Stock Exchange in the period of 1995. They find that higher government ownership is positively associated with corporate voluntary disclosure. Consistently, Conyon and He (2011) they examined a sample of 1342 firms from Chinese listed firms during 2001-2005. They find that there is relationship between ownership and corporate governance practices. Similarly, Ntim et al. (2012a) shows that the government ownership is positively associated with voluntary corporate disclosure among 169 South African listed firms. The Saudi government has high ownership stakes in a considerable number of firms, representing an average of $42 \%$ of the total value of the Saudi stock market. Apart from Al-Moataz and Lakhal (2012), no study has explored the impact of government ownership on CSR disclosure. Based on the above discussion, the current study hypotheses the following:

\section{H 3 a: There is an association between Government ownership and CSR disclosure quantity.}

\section{H 3 b: There is a relationship between Government ownership and CSR disclosure quality.}

\section{3-4 Managerial ownership}

The agency theory indicates that the increase of managerial ownership levels could be of interest to managers and stakeholders, in particular the shareholders. This may be because firms with a higher percentage of managerial ownership are likely to align the interests of both managers and shareholders and consequently they would have lower agency costs (Jensen and Meckling, 1976). Hence, a positive association is expected between managerial ownership and corporate voluntary disclosure. Prior studies showed a positive association between managerial ownership and corporate voluntary disclosure (e.g. Chau and Gray, 2002; Jaing and Habib, 2009). In contrast, Eng and Mak (2003) find a negative relationship between managerial ownership and the quality of corporate disclosures.

Based on the agency and stakeholder theories, it is anticipated that managers with a high interest in the company's engage could be motivated to extend the level of the quantity and quality of CSR disclosures. This conduct would be explained by the manager's objective to 
reduce the agency problem (agency theory) and to achieve the vital information the stakeholders' need (stakeholder theory). Thus, the following hypothesis is formulated:

\section{$H$ 4a: There is an association between Managerial ownership and CSR disclosure quantity.}
H 4b: There is a relationship between Managerial ownership and CSR disclosure quality.

\section{3-5 CEO Duality}

Chef executive officer (CEO) duality is considered to be a suitable system for operating a company (Donaldson and Davis, 1991; Siebels and Knyphausen-Aufseb, 2012). Particularly, when the agents have access to the information, this increases their ability to work towards firm welfare (Nicholson and Kiel, 2007). In addition, the CEO duality is an important factor of corporate governance because of its sensitive nature, due to the association between the agents and principles (Davis et al., 1997; Krause et al., 2014). The agency theory suggests that CEO could run a firm to achieve the satisfaction of shareholders (Jensen and Meckling, 1976; Chen et al., 2011). Prior research (e.g., Lipton and Lorsch, 1992; Mashayekhi and Bazaz, 2008) suggests that the role of CEO duality can offer some opportunities to selfserving CEOs. This means they have control over board meetings, and therefore, may negatively affect the corporate financial performance. Moreover, CEOs attempt to protect their reputation and to find ways of improving their chances in the future (Conyon and $\mathrm{He}$, 2011). Consequently, they attempt to do their best for their firms to acquire more profit and increase the value of their firms (Davis et al., 1997; Nicholson and Kiel, 2007; Siebels and Knyphausen-Aufseb, 2012). Christensen et al. (2014) find that the separation of the roles of CEO and chairman is significantly associated with higher earnings quality among 660 Australian companies between the periods of 2001 to 2004. in contrast, some previous research shows a positive association between CEO duality and a firm's financial performance. For instance, Brickley et al. (1997) find that CEO duality roles have a positive impact on the financial performance of a firm. Based on the above discussion, the current study develops the following hypotheses:

H 5 a: There is an association between CEO Duality and CSR disclosure quantity. $\mathrm{H} 5 \mathrm{~b}$ : There is a relationship between CEO Duality and CSR disclosure quality. 


\section{3-6 Board meeting frequency}

The frequent board meeting is an essential tool to a corporate governance mechanism because it helps the directors of the board to control operation of the firm effectively. Thus, active and frequent meetings of the board can monitor the financial reporting of an entity. Consistently, some prior research finds a positive association between board meetings and financial reporting of a company. This is also consistent with signalling theory. However, there is limited literature that examines the association between frequency of board meetings and corporate disclosure in the UK (Alzahar, 2013). Laksamana (2008) reports a positive association between board meetings and the transparency of compensation disclosure. Anis, et al. (2012) reported that one of the board duties is to oversee management practices; one of these practices is the disclosure of voluntary information. Therefore, the higher the frequency of meetings, the more effective the board will be, or more specifically, more time will be expected to be allocated for overseeing voluntary disclosure and this is consequently promoting disclosure quality. In addition, Anis, et al. (2012) finds a positive relationship between the frequency of board meetings and the level of disclosure quality. Accordingly, with the consensus about the positive influence of board meeting frequency, based on the above findings, the current study hypotheses the following:

\section{H 6 a: There is an association between board meetings and CSR disclosure quantity.}

H 6 b: There is a relationship between board meetings and CSR disclosure quality.

\section{3-7 Audit committee size}

The audit committee has an essential role in improving disclosure levels of financial reports (Al Janadi et al., 2013). The agency theory plays a role to explain the problem between the principal and the agent (Bruton et al., 1997). However, there is limited research to study the association between voluntary disclosure and the audit committee. In addition, some research argues that the audit committee is considered to be the monitoring tool, which improves the quality of corporate disclosure, which in turn reduces the agency costs. Furthermore, Hoe and Wong (2001) report that the existence of an audit committee significantly affects the level of corporate disclosure. Moreover, small audit committees may not be in a position to have enough resources. Consequently, this may adversely affect the quality of their oversight (Fleo et al., 2009). In addition, organisational behaviour research maintains that large audit committees are likely to be less productive (Jensen, 1993; Karamanou and Vafeas, 2005). 
Some previous research (Li, Pike and Haniffa, 2008: O'Sullivan, Percy, and Stewart, 2008) reports that a positive association exists between the audit committee size and the levels of voluntary disclosure. Similarly, another study finds a positive relationship between the audit committee size and corporate reporting (Albassam, 2014). Therefore, the following hypotheses are formulated as follows:

H 7 a: There is an association between audit committee size and CSR disclosure quantity.

H 7 b: There is a relationship between audit committee size and CSR disclosure quality.

\section{3-8 Remuneration committee size}

One of the corporate governance mechanisms is the remuneration committee size. However, there is no theory, nor a well-acknowledged argument that explains the association between the number of members of a remuneration committee and the quality of disclosure (Anis et al., 2012). Prior research suggests that there is insignificant relationship between remuneration committee size and disclosure quality. This is because it is indicated that $6 \%$ of the sample falls less than the governance code of $(2008)^{1}$, which requires the size of the remuneration committee to consist of at least three members. The governance code (2008) holds that "The board should establish an audit committee of at least three or in the case of smaller companies' two, independent non-executive directors" (FRC, 2008; para C.3.1). Moreover, prior research that examines the association between the size of the remuneration committee and voluntary disclosure is limited. It finds no significant relationship between the remuneration committee size and the quality of disclosure. However, it is argued that it might be likely that a higher committee size may positively affect the level of quality of disclosure (Anis et al., 2012). Although of Anis et al., (2012) argument, there is no strong evidence regarding the association between the remuneration committee and disclosure quality. Obviously, it is argued that there is little evidence about the effectiveness of remuneration committees in the UK (Ezzamel and Watson, 1997). Therefore, based on the above discussion, the current study develops the following hypotheses:

\section{$\mathrm{H} 8$ a: There is an association between remuneration committee size and CSR disclosure quantity.}

$\mathrm{H} 8 \mathrm{~b}$ : There is a relationship between remuneration committee size and CSR disclosure quality.

\footnotetext{
${ }^{1}$ This is the same governance code applied to companies in Saudi Arabia.
} 


\section{3-9 Auditor type}

Prior research suggests that the quality of the auditor is an important factor in improving the firms' overall reporting practices (e.g. Hail, 2002; Hussainey et al. 2011; Hassanein and Hussainey, 2015). Additionally, it is anticipated that big auditing firms are more likely to facilitate the diffusion of innovative practices, such as CSR disclosure (Xiao et al., 2004). However, previous studies reports mixed results in terms of the association between disclosure and audit type (e.g. Ahmed and Nicholls, 1994; Raffournier, 1995; Xiao et al., 2004). They find a positive relationship between auditor type and disclosure of voluntary information. In addition, some prior research finds a positive relationship between auditor type and voluntary disclosure (e.g., Abd-Elsalam \& Weetman, 2003); Hossain et al., 1995; Wallace et al., 1994).

Samaha and Dahawy (2011) and Aly et al. (2010) find no association between the disclosure of CSR information and auditor type in the Egyptian context. They examine the association between auditor type and the overall disclosure quality in order to improve the quality and to provide accurate information that it enhances the stakeholder's decision. It is essential to the stakeholders to be concerned with specific social and environmental aspects of performance (Adams, 2002). Therefore, this study develops the following hypotheses:

\section{H 9 a: There is association between auditor type and CSR disclosure quantity.}

$\mathrm{H} 9$ b: there is relationship between auditor type and CSR disclosure quality.

\section{RESEARCH DESIGN}

\subsection{Sample}

This study uses samples from the annual reports of Saudi Arabian firms listed in the Tadawul Stock Exchange over the period of 2013-2014. This period is chosen because it is quite close to the declaration of the Saudi governance code that includes the social contribution. Furthermore, it is the most recent annual report containing enhanced quality and quantity CSR and its impact is expected given that the code has been adopted since 2010. In addition, non-financial companies are more likely to be utilised with social and environments (Brammer and Pavelin, 2008).

The total number of non-financial companies listed in Saudi Stock Exchange for years 20132014 is 198. Following prior research (e.g., Hassanein and Hussainey, 2015; Elshandidy, 
Fraser, and Hussainey, 2013; Elzahar et al., 2015) financial firms are excluded. In addition, we have excluded firms with missing financial data. This leaves us with 171 firm-year observations. Table (1) shows the final sample sorted by industries.

\begin{tabular}{|l|c|c|}
\hline Table 1: Industry Classification & $\mathbf{N}$ & $\mathbf{\%}$ \\
\hline Industry & 28 & $16.4 \%$ \\
\hline Basic material & 27 & $15.8 \%$ \\
\hline Consumer goods & 35 & $20.5 \%$ \\
\hline Consumer services & 66 & $38.6 \%$ \\
\hline Industrials & 4 & $2.3 \%$ \\
\hline Real Estate & 7 & $4.1 \%$ \\
\hline Telecommunication & 4 & $2.3 \%$ \\
\hline Utilities & $\mathbf{1 7 1}$ & $\mathbf{1 0 0 \%}$ \\
\hline Total & \multicolumn{2}{|l|}{} \\
\hline $\begin{array}{l}\text { This Table provides the distribution of industries of the sample. The definitions of the } \\
\text { industries are based on the Industry Classification Benchmark (ICB). }\end{array}$
\end{tabular}

Annual reports are collected from companies' official websites. Governance data is manually collected from the companies' annual reports. All financial data is collected from DataStream.

\subsection{CSR disclosure index}

This study develops two disclosure indices, one to measure the level of CSR disclosure quantity, and the other to measure the level of CSR disclosure quality. The disclosure index of CSR disclosure quantity is based on prior research (e.g., Hackston \& Milne, 1996); Hall, 2002; Newson \& Deegan, 2002). This index consists of seven disclosure categories, which are: 1) employees, 2) communities, 3) environmental issues, 4) products and services, 5) energy, 6) customers, and 7) other disclosure items, which are consistent and compatible with the Saudi Arabia culture and its economic environment. In determining the CSR disclosure quantity, an unweighted disclosure is commonly utilised. This approach has been adopted by several researchers in which an item scores one if it is disclosed and zero if it is not disclosed (Abdurouf, 2011; Haji, 2013; Aribi and Gao, 2010; Anwar et al., 2010). Appendix 1 details the disclosure index for CSR disclosure quantity.

In terms of the index that measures CSR disclosure quality, it is based on the qualitative characteristics of accounting information suggested in the conceptual framework of the 
International Financial Reporting Standards (IFRS). Following prior research (e.g., Botosan, 2004; Jonas and Blanchet, 2000); Beest et al., 2009), this study develops a disclosure index to measure the level of CSR quality based on the qualitative characteristics of information discussed in the conceptual frameworks. In addition, Beest et al. (2009) develop a comprehensive measure to operationalize and to enhance the qualitative characteristic of annual reports' information.

Following Beest et al. (2009), Chakroun and Hussainey (2014), this study measures the level of quality of CSR disclosure in Saudi Arabian firms weighted based on the qualitative characteristics of the financial information. Consequently, the study adopted 4themes (characteristics) which are "Relevance", "Faithful representation", "Understandability" and "Comparability" to assess the level of quality of CSR disclosure in the annual report. This allows for the evaluation of the qualitative characteristics of financial information by weighted measure as provided in earlier studies (Beest et al., 2009; Chakroun \& Hussainey, 2014). The study adopted the four qualitative characteristics of CSR information: "relevance," "faithful representation," "understandability" and "comparability 3 " to assess the CSR disclosure quality in Annual Reports. The reliability and validity of our disclosure scores are checked by comparing the correlation between the scores produced by the first author with those produced by the second author for a sample of annual reports. Appendix 2 details the disclosure index for CSR disclosure quality.

Prior research (e.g., Milne and Adler, 1999; Haji, 2013; Hassanein and Hussainey, 2015) suggest that the researchers should pay attention to the reliability and validity of their disclosure indices. Consequently, the CSR disclosure indices of the quantity and quality have been tested for reliability and validity.

The checklists were improved through revising the draft twice before making it final, to enhance the criterion and content validity. Accordingly, we ensured that the draft of the CSR disclosure indices were discussed in BAFA conferences, where comments were received from experienced researchers in the field of CSR. Following previous studies (e.g. Ng 1995; Abdurouf 2011; Haji 2013) after designing the initial checklist, it was reviewed independently by both the principal and the second supervisor in order to achieve instrument

\footnotetext{
${ }^{3}$ Definition of each characteristic is included in Appendix 2.
} 
validity. All suggestions and comments were discussed and considered in order to improve the validity of the instrument.

Further, following prior research (e.g., Botosan, 1997) we use analytical analysis to check the validity of the CSR disclosure score. This is done by examining the association between CSR disclosure scores (quantity and quality) and the firm characteristics. Further, in the empirical results in section (4), the study finds that CSR disclosure quantity is positively associated with board size, audit committee size, company size, and negatively associated with governmental ownership, remuneration committee size, firm leverage and dividends paid. In addition, the CSR disclosure quality is positively associated with board size, managerial ownership, firm size and firm leverage and negatively associated with independent directors and dividends paid. These results add validity to our disclosure indices (quantity and quality).

This study ensures the reliability of the disclosure indices (quantity and quality) in the following way. Following the previous research (e.g. Linsley and Shrives, 2006), decision rules were produced and used as a coding reference to improve the reliability. Then, the researcher and the two supervisors coded the annual reports of the sample in the pilot study, independently. This procedure aimed to ensure consistency in applying the checklist of CSR disclosure based on the qualitative characteristics to measure the CSR disclosure quality. Finally, the results obtained were checked, and found to be close.

\subsection{Regression model}

To test the hypotheses related to the association between CSR disclosure quantity and governance mechanisms (H1a, H2a, H3a, H4a, H5a, H6a, H7a, H8a and H9a), the study controls for some firm specific characteristics that are identified in prior research as determinants of CSR disclosure. These variables are firm profitability, size, liquidity, leverage and dividends. Moreover, the CSR disclosure may be affected by the implementation of some accounting regulations or may be affected by some industry specific characteristics. Therefore, the year and industry fixed effects are used to control for variations in CSR disclosures due to this reason. Equation (1) summarises the empirical model.

\footnotetext{
CSRQuan $=\beta_{0}+\beta_{1}$ BSIZE $+\beta_{2}$ INDTO $+\beta_{3}$ GOVWN $+\beta_{4}$ MANOW $+\beta_{5}$ CEOD $+\beta_{6}$ BMET$$
+\beta_{7} \text { ACZISE }+\beta_{8} \text { REMCOSZE }+\beta_{9} \text { AUDYPE }+\beta_{10} \text { PROF }+\beta_{11} \text { SIZE }+\beta_{12} \text { LIQ }+\beta_{13}
$$$$
\text { LEV+ } \beta_{14} \text { DIVI + Year Fixed Effect + Industry Fixed Effect }
$$ 
CSRQuan is the quantity of CSR disclosure, BSZE is the total number of directors on the board; INDTO is the number of independent directors in the firm board of directors, GOVWN Percentage of shares owned by government, MANOW is the aggregate percentage of shares held by major shareholders (with at least 3\% ownership), CEOD is a dummy variable equals 1 if the chairman is the same person as the CEO of the firm, 0 otherwise BMET is the total number of board meetings during the year; ACSZE is the is the total number of directors in audit committee; REMCOSZE is the number of members of the firm remuneration committee, AUDYPE is a dummy variable that is equal to 1 if the firm is audited by one of the big 4 audit firms and 0 otherwise. PROF is firm profitability, measured using returns on the assets ratio; SIZE is the firm size, measured using the value of total assets; LIQ is firm liquidity, measured using the current ratio (current assets / current liabilities); LEV is firm leverage, measured using the ratio of total liabilities to total assets, DIVI is the total dividends paid to common shareholders.

Consistently, to test the hypotheses related to the association between CSR disclosure quality and governance mechanisms (H1b, H2b, H3b, H4b, H5b, H6b, H7b, H8b and H9b), the study controls for some firm specific characteristics that have been identified in prior research as determinants of CSR disclosure. These variables are firm profitability, size, liquidity, leverage and dividends. Besides, the CSR disclosure may be affected by the implementation of some accounting regulations or may be affected because of some industry specific characteristics. Therefore, the year and industry fixed effects are used to control for variations in CSR disclosures due to this reason. Equation (2) summarises the empirical model.

\section{CSRQual $=\beta_{0}+\beta_{1}$ BSIZE $+\beta_{2}$ INDTO $+\beta_{3}$ GOVWN $+\beta_{4}$ MANOW $+\beta_{5}$ CEOD $+\beta_{6}$ BMET \\ $+\beta_{7}$ ACZISE $+\beta_{8}$ REMCOSZE $+\beta_{9}$ AUDYPE $+\beta_{10}$ PROF $+\beta_{11}$ SIZE $+\beta_{12}$ LIQ $+\beta_{13}$ \\ LEV $+\beta_{14}$ DIVI + Year Fixed Effect + Industry Fixed Effect

\section{Where:}

CSRQual is the quality of CSR disclosure; BSZE is the total number of directors on the board; INDTO is the number of independent directors in the firm board of directors, GOVWN is the percentage of shares owned by government, MANOW is the aggregate percentage of shares held by major shareholders (with at least 3\% ownership), CEOD a dummy variable, equals 1 if the chairman is the same person as the CEO of the firm, 0 otherwise BMET is the total number of board meetings during the year; ACSZE is the total number of directors in audit committee; REMCOSZE is the number of members in the firm remuneration committee, AUDYPE Dummy variable that is equal to 1 if the firm is audited by one of the big 4 audit firms and 0 otherwise. PROF is firm profitability, measured using returns on the assets ratio; SIZE is the firm size, measured using 
the value of total assets; LIQ is firm liquidity, measured using the current ratio (current assets / current liabilities); LEV is firm leverage, measured using the ratio of total liabilities to total assets, DIVI is the total dividends paid to common shareholders.

\section{5- RESULT ANALYSIS}

\subsection{Descriptive statistics:}

Table (4.2) details the descriptive statistics of all variables. The mean value of the CSR disclosure quantity (CSRQuan) is 9.433 (.334), which reveals that the value of the CSR disclosure quantity in Saudi Arabian firms is higher than the value of the CSR disclosure quality. In addition, the minimum and maximum values of the CSR disclosure quantity range from .000 to 51.00 respectively. However, the minimum and maximum values of the CSR disclosure quality range from 1.00 to 1.3 respectively.

In terms of governance mechanisms, the mean value of board size (BSZE) is 8.485 with a minimum value of 4.0 and a maximum value of 12.0. This means that the board size of Saudi Arabian firms ranges from four members on the board to twelve members. The mean value of the percentage of independent directors (INDTOR) on the board is 4.064 with a minimum value of 0.00 and a maximum value of 11.0. In terms of ownership structure, the mean value of governmental ownership (GOVWN) is .032 and minimum and maximum values are .000 and 0.743 , respectively. In addition, the mean value of managerial ownership (MANOWR) is .055 and the minimum is .000 whilst the maximum is 0.700 . The mean value of the role duality of CEO (CEOD) is .357 with a minimum value of .000 and a maximum value of 1.0. The mean value of board meeting (BMET) is 5.292; whereas, the minimum value is 0.000 , and the maximum value is 16.0. The audit committee size (ACSZE) of Saudi Arabian firms has a mean value of 3.316 and its minimum value is .000 and its maximum value is 6.0. Furthermore, the mean value of remuneration committee size (REMUCOSZE) is 3.368 and the minimum value is .000 and the maximum value is 7.0. Finally, the auditor type (AUDYPE) has a mean value of .632 with minimum and maximum values of.000 and 1.0, respectively.

With regards to firm characteristics, the mean value of firm profitability (PROF) is 13.242 with a minimum value of -60.94 and a maximum value of 59.410. Firm size (SIZE), has a minimum value of 11.268 , a maximum value of 19.643 , and a mean value of 14.720 . Firm liquidity (LIQ) has minimum and maximum values of .070 and 5.770, respectively. Firm 
leverage (LEV) has a minimum value of .000 and a maximum value of 354.910 , with a mean value of 57.961. The dividends paid (DIVI0 have a mean value of 493507 and the minimum and maximum of .000 and 18502401 , respectively. 


\begin{tabular}{|c|c|c|c|c|c|c|c|c|}
\hline \multicolumn{9}{|c|}{ Table (4.2): Sample descriptive statistics } \\
\hline & $\mathbf{N}$ & Mean & Std Dev. & Minimum & $25 \%$ & $\begin{array}{c}\text { Medium } \\
\text { (50\%) }\end{array}$ & $75 \%$ & Maximum \\
\hline CSRQuan & 171 & 9.433 & 9.517 & .000 & 2.000 & 6.000 & 15.000 & 51.0 \\
\hline CSRQual & 171 & .334 & .141 & .100 & .20000 & .325 & .425 & 1.300 \\
\hline BSZE & 171 & 8.485 & 1.606 & 4.0 & 7.000 & 9.000 & 9.000 & 12.0 \\
\hline INDTOR & 171 & 4.064 & 1.587 & .000 & 3.000 & 4.000 & 5.000 & 11.0 \\
\hline GOVWN & 171 & .032 & .134 & .000 & .000 & .000 & .000 & .7431 \\
\hline MANOWR & 171 & .055 & .126 & .000 & .000 & .000 & .045 & .7000 \\
\hline CEOD & 171 & .357 & .480 & .000 & .000 & .000 & 1.000 & 1.0 \\
\hline BMET & 171 & 5.292 & 2.323 & .000 & 4.000 & 5.000 & 6.000 & 16.0 \\
\hline ACSZE & 171 & 3.316 & .929 & .000 & 3.000 & 3.000 & 4.000 & 6.0 \\
\hline REMUCOSZE & 171 & 3.368 & 1.067 & .000 & 3.000 & 3.000 & 4.000 & 7.0 \\
\hline AUDYPE & 171 & .632 & .483 & .000 & .000 & 1.000 & 1.000 & 1.0 \\
\hline PROF & 171 & 13.242 & 15.597 & -60.94 & .000 & 13.010 & 20.570 & 59.410 \\
\hline SIZE & 171 & 14.720 & 1.622 & 11.268 & 13.80 & 14.551 & 15.280 & 19.643 \\
\hline LIQ & 171 & 1.393 & 1.275 & .070 & .480 & .960 & 1.770 & 5.770 \\
\hline LEV & 171 & 57.961 & 67.515 & .000 & 8.20 & 32.760 & 87.490 & 354.910 \\
\hline DIVI & 171 & $\begin{array}{c}49350 \\
7\end{array}$ & 1858755 & .000 & 23.000 & 65000 & 306000 & 18502401 \\
\hline \multicolumn{9}{|c|}{$\begin{array}{l}\text { CSRQuan refers to the quantity of CSR disclosure; CSRQual is the quality of CSR disclosure; BSZE is the total number of } \\
\text { directors on the board; INDTO is the number of independent directors in the firm board of directors, GOVWN is the percentage of } \\
\text { shares owned by government, MANOW is the aggregate percentage of shares held by major shareholders (with at least } 3 \% \\
\text { ownership), CEOD is a dummy variable equals } 1 \text { if the chairman is the same person as the CEO of the firm, } 0 \text { otherwise BMET is } \\
\text { the total number of board meetings during the year; ACSZE is the is the total number of directors in audit committee; REMCOSZE } \\
\text { is the number of members in the firm remuneration committee, AUDYPE is a dummy variable that is equal to } 1 \text { if the firm is audited } \\
\text { by one of the big } 4 \text { audit firms and } 0 \text { otherwise, PROF is firm profitability, measured using returns on the assets ratio; SIZE is the } \\
\text { firm size, measured using the value of total assets; LIQ is firm liquidity, measured using the current ratio (current assets / current } \\
\text { liabilities); LEV is firm leverage, measured using the ratio of total liabilities to total assets, DIVI is the total dividends paid to } \\
\text { common shareholders. }\end{array}$} \\
\hline
\end{tabular}




\subsection{Correlation analysis}

According to Gujarati and Porter (2009), high correlation among variables might cause a problem of multi-collinearity ${ }^{4}$. If there is problem of multi-collinearity the reliability of the estimates is affected (Acock, 2008). Moreover, the problem of multi-collinearity might cause a problem in terms of evaluating the significance variables in regression. Therefore, it is required to match the aggregate correlation among all the independent variables (Tabachnick \& Fidell, 2007).

The Pearson correlation matrix is a basic tool to detect the multi-collinearity problem. Gujarati and Porter (2009) pointed that variables have a high correlation if the correlation is bigger than 0.80 . Therefore, multi-collinearity among variables is accepted if the correlation coefficients are less than 0.80 .

Table (4.3) shows the Pearson correlation matrix among all the independent and dependent variables used in this study. Pearson coefficients are relatively low among all variables, less than 0.80 , indicating that there is no multi-collinearity problem.

An additional check for multi-collinearity is performed by calculating the Variance Inflation Factor (VIF) after each regression model. Prior research indicates that if the VIF value is more than 10, thus, this suggests a multi-collinearity problem. The mean and maximum values of the VIF tests are tabulated with the regression result and show that there is no concern about this problem (Field, 2009).

The Pearson correlation matrix is also used to measure the strength and direction of the linear relationship between two variables. It provides evidence that CSRD quantity is statistically correlated positively with some corporate governance variables such as BSZE at .182 (10\% significance level), CEOD at .191 (10\% significance level), ACSZE .173 (10\% significance level), and with firm characteristics such as firm size at .273 (5\% significance level), dividends paid at .287 (5\% significance level). However, the CSR disclosure quality is associated positively with board size at .155 (10\% significance level), managerial ownership at .216 (5\% significance level) and with firm characteristics such as firm size at $.206(5 \%$ significance level) and dividend paid at .292 (10\% significance level).

\footnotetext{
${ }^{4}$ Multi-collinearity (also, multicolinearity or colinearity) exists when two or more variables are highly correlated, meaning that one can be linearly predicted from the other (Tabachnick \& Fidell, 2007; Gujarati \& Porter, 2009).
} 
Moreover, the Pearson correlation matrix indicates significant association between CSR disclosure quantity and quality with some firm characteristics variables. This study finds that there is a positive relationship between CSR disclosure quantity and quality, which are both significantly correlated with firm size and dividend paid respectively $.206, \quad 292$ (5\% significance level).

This result is consistent with some prior research (e.g. Laksamana, 2008; Hussainey and AlNajjar, 2011) who suggest that the corporate governance variables are associated with firm disclosure. Regarding previous research, the firm characteristics results by Wang and Hussainey, (2013) and Naser et al. (2006) suggest the firm characteristics relationship with firmdisclosure. 


\begin{tabular}{|c|c|c|c|c|c|c|c|c|c|c|c|c|c|c|c|c|}
\hline & 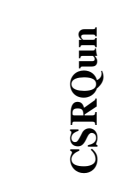 & 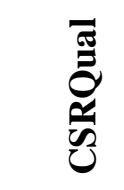 & 椞 & 官 & $\sum_{0}^{Z}$ & $\begin{array}{l}3 \\
0 \\
z \\
z\end{array}$ & $\begin{array}{l}\widehat{0} \\
\text { 풘 }\end{array}$ & $\sum_{i=0}^{n}$ & $\begin{array}{l}\text { Nov } \\
\text { 己 }\end{array}$ & 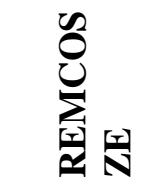 & 帘 & $\begin{array}{l}\frac{1}{0} \\
\stackrel{x}{a}\end{array}$ & $\frac{\sqrt{N}}{\mathrm{~N}}$ & రి & 空 & $\bar{a}$ \\
\hline $\mathbf{N}$ & 171 & 171 & 171 & 171 & 171 & 171 & 171 & 171 & 171 & 171 & 171 & 171 & 171 & 171 & 171 & 171 \\
\hline \multirow{2}{*}{ CSRQuan } & 1 & $.605^{* *}$ & $.182 *$ & .001 & .079 & .021 & $.191 *$ & .063 & $.173^{*}$ & .000 & .068 & .135 & $.273 * *$ & -.095 & -0.08 & $.287 * *$ \\
\hline & & .000 & .017 & .991 & .301 & .788 & .012 & .414 & .024 & .996 & .377 & .077 & .000 & .216 & .914 & .000 \\
\hline \multirow{2}{*}{ CSRQual. } & & 1 & $.155^{*}$ & -.095 & .072 & $.216 * *$ & .079 & -.036 & .107 & .042 & .103 & .078 & $.206^{* *}$ & -.099 & .017 & $.292 * *$ \\
\hline & & & .043 & .217 & .351 & .004 & .301 & .639 & .166 & .587 & .181 & .312 & .825 & .196 & .007 & .000 \\
\hline \multirow{2}{*}{ BSZE } & & & 1 & $.352 * *$ & .089 & -.020 & .049 & .047 & $.165^{*}$ & $.286 * *$ & $.216^{* * *}$ & .136 & $.392 * *$ & .081 & -.004 & .088 \\
\hline & & & & .000 & .245 & .798 & .527 & .543 & .031 & .000 & .004 & .076 & .000 & .291 & .956 & .253 \\
\hline \multirow{2}{*}{ INDTO } & & & & 1 & -.099 & .049 & -.038 & .011 & .062 & -.018 & -.092 & .054 & .046 & -.074 & -.066 & -.087 \\
\hline & & & & & .200 & .525 & .622 & .888 & .421 & .820 & .234 & .480 & .546 & .339 & .390 & .257 \\
\hline \multirow{2}{*}{ GOVWN } & & & & & 1 & -.107 & -.022 & .119 & $.278 * *$ & $.254 * *$ & $.185^{*}$ & -.104 & $.459 * *$ & $.22 *$ & -.030 & $.495 * *$ \\
\hline & & & & & & .163 & .771 & .122 & .000 & .001 & .015 & .177 & .000 & .003 & .701 & .000 \\
\hline \multirow{2}{*}{ MANOW } & & & & & & 1 & -.050 & $-.155^{*}$ & -.098 & -.089 & .023 & $.179^{*}$ & -.070 & -.069 & -.064 & -.070 \\
\hline & & & & & & & .514 & .043 & .202 & .246 & .767 & .019 & .362 & .369 & .408 & .365 \\
\hline \multirow{2}{*}{ CEOD } & & & & & & & 1 & -.073 & .062 & -.017 & .037 & .149 & .037 & -.147 & -.033 & $.177^{*}$ \\
\hline & & & & & & & & .343 & .418 & .826 & .628 & .052 & .630 & .055 & .670 & .021 \\
\hline \multirow{2}{*}{ BMET } & & & & & & & & 1 & $.172 *$ & $.189^{*}$ & .013 & .007 & $.156^{*}$ & -.073 & -.113 & $.158^{*}$ \\
\hline & & & & & & & & & .024 & .013 & .869 & .925 & .042 & .346 & .143 & .040 \\
\hline \multirow{2}{*}{ ACSZE } & & & & & & & & & 1 & $.635 * *$ & .064 & .018 & $.307 * *$ & .121 & .001 & $.216^{* * *}$ \\
\hline & & & & & & & & & & .000 & .406 & .815 & .000 & .116 & .986 & .004 \\
\hline \multirow{2}{*}{ REMCOSZE } & & & & & & & & & & 1 & .128 & .121 & $.253 * *$ & .090 & -.021 & $.249 * *$ \\
\hline & & & & & & & & & & & .096 & .115 & .001 & .241 & .786 & .001 \\
\hline \multirow{2}{*}{ AUDYPE } & & & & & & & & & & & 1 & .123 & $.291 * *$ & .165 & -.029 & $.154 *$ \\
\hline & & & & & & & & & & & & .109 & .000 & .031 & .705 & .044 \\
\hline \multirow{2}{*}{ PROF } & & & & & & & & & & & & 1 & .034 & -.273 & .124 & .117 \\
\hline & & & & & & & 24 & & & & & & .663 & .000 & .107 & .128 \\
\hline Size & & & & & & & & & & & & & 1 & -.301 & -.096 & .122 \\
\hline
\end{tabular}




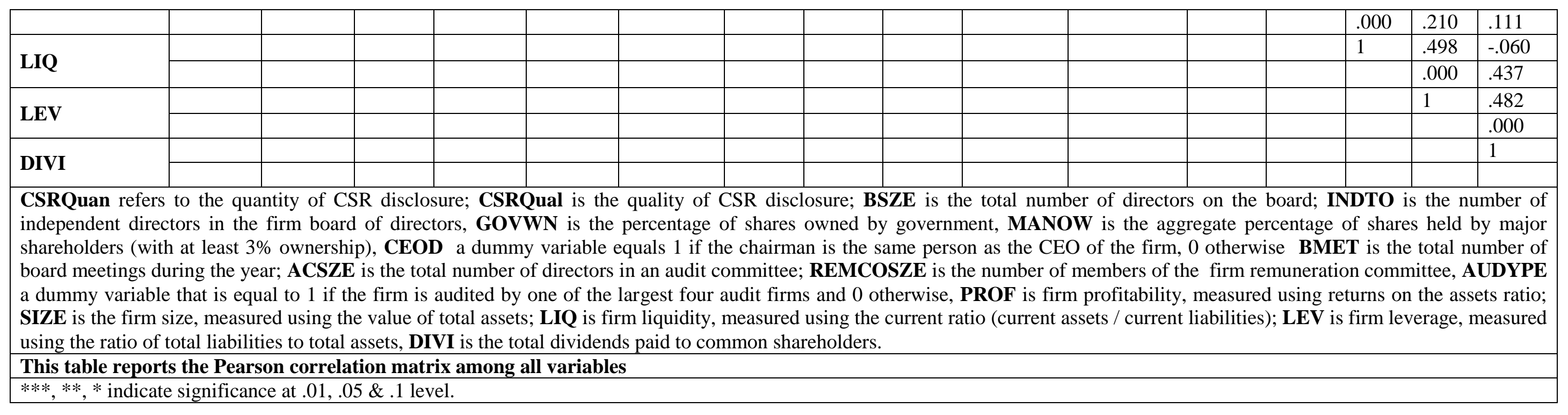




\subsection{Regression analysis}

Table (4.4) summarises the results of OLS regression analysis of the relationship between CSR disclosure and corporate governance mechanisms. Panel A reports the results of the CSR disclosure quantity (Model 1), while, panel B reports the results of the CSR disclosure quality (Model 2). It is apparent that the F-values of Models 1 and 2 are 5.800 ( $1 \%$ significance level) and 2.564 at (1\% significance level) respectively. These values indicate that both models 1 and 2 are statistically significant. Moreover, the adjusted R-Squared values of models 1 and 2 are $.37 .2 \%$ and $16 \%$ respectively. These values imply that model 1 explains $37 \%$ of total variation in CSR disclosure quantity and model 2 explains $16 \%$ of the CSR disclosure quality. In sum, both models 1 and 2 are statistically effective for explaining the variation in the extant of CSR disclosure quantity and quality. Overall, their values imply a good overall fit of the models.

The coefficient for CSRQuan on BSZE is .826 and is statistically significant at $10 \%$ level of significance. This result indicates that CSR quantity is positively associated with -board size. In other words, the result suggests that the quantity of CSR disclosure increases as long as board size increases. Therefore, the researcher accepts the H1a hypothesis that an association exists between CSR disclosure quantity and board size. In addition, it finds that the coefficient for CSRQual on the BSZE is .016 and is statistically at $10 \%$ level of significance. This result indicates that CSR disclosure quality is positively associated with board size, meaning that the quality of CSR disclosure quality increases as long as the size of the board of directors increases. Therefore, the researcher accepts $\mathrm{H} 1 \mathrm{~b}$ that an association exists between CSR disclosure quality and board size.

The results are consistent with the expectations of the agency and signaling theories. Shareholders of a firm expect a high level and quality of disclosure from the board of directors, as they have been selected to represent their interests (Davidson et al., 1998). In addition, the agency theory proposes that board size is a crucial factor in monitoring management behavior (Fama and Jensen, 1983; Allegrini and Greco, 2013). Furthermore, based on the signaling theory, a positive association between board size and voluntary disclosure is expected.

The results are also consistent with prior research (e.g., Brammer \& Pavelin, 2006 and 2008; Laksamana, 2008; Hussainey and Al-Najjar, 2011, Schiehll et al. 2013) who find a positive 
association between voluntary disclosure and board size. However, some prior research provides a negative relationship between board size and voluntary disclosure (e.g. Cerbioni \& Parbonetti, 2007). Others find there to be no significant impact in terms of board size on corporate disclosure (e.g. Lakhal, 2005; Cheng and Courtenay, 2006).

The coefficient of CSRQuan on INDTOR is -.367 and is not statistically significant at any level of significance. This result indicates that the CSR disclosure quantity is not significantly associated with the percentage of independent directors. Therefore, the researcher rejected the $\mathrm{H} 2 \mathrm{a}$ hypothesis that an association exists between the CSR disclosure quantity and independent directors. On the other hand, the coefficient of CSRQual on INDTOR is -.015 and is statistically at 5\% level of significance. This result indicates that the CSR quality is negatively associated with the percentage of independent directors, meaning that the existence of independent directors on the board of directors decreases the quality of the CSR disclosure. Therefore, the $\mathrm{H} 2 \mathrm{~b}$ hypothesis is accepted in that an association exists between the CSR disclosure quality and the percentage of independent directors.

The results could be explained according to the agency theory and some prior research. Beak et al. (2009) study established a positive association between the amount of outside directors on boards and the comprehensiveness of financial disclosure. In addition, some -studies finds a negative association between outside directors on the boards and the levels of voluntary disclosure (Barako, Hancock and Izan, 2006; Hoitash and Bedard, 2009). Other studies find no association between the CSR disclosure and independent directors (e.g. Hoe and Wong, 2001; Haniffa and Cooke, 2002).

This study finds that the coefficient for CSRQuan on GOVWN is -.16.5 and is statistically significant at $5 \%$ level of significance. This result indicates that the CSR disclosure quantity is negatively associated with governmental ownership, meaning that the quantity of the CSR disclosure is reduced when governmental ownership exists. Therefore, the H3a hypothesis is accepted. On the other hand, the coefficient of CSRQual on GOVWN is -.168 and is not statistically significant at any level of significance. This result suggests that there is no impact of governmental ownership on the CSR disclosure quality. Therefore, the H3b hypothesis is rejected.

From a stakeholder theory perspective, state (government) ownership is a key factor influencing corporate governance disclosure; particularly in emerging countries where 
concentrated ownership structures are widespread (Shleifer, 1998; Cornett et al., 2010; AlMoataz and Hussainey, 2012). Some prior research finds that a positive relationship exists between governmental ownership and voluntary disclosure (Baek at el. 2009; Makhija and Patton, 2004). However, the result is consistent with prior research (e.g., Liu et al. 2014; Barth at el. 1999; Similarly, Luo et al. 2006) who find a negative association between voluntary disclosure and governmental ownership.

The coefficient for CSRQuan on MANOWR is -1.77 and is not statistically significant at any level of significance. This result indicates that the percentage of managerial ownership has no effect on the level of the CSR disclosure quantity. Therefore, the researcher rejects the H4a hypothesis that an association exists between the CSR disclosure quantity and managerial ownership. However, the coefficient of CSRQual on MANOWR is .233 and is statistically significant at $10 \%$ level of significance. This suggests that the CSR disclosure quality increases as long as the percentage of managerial ownership increases. Therefore, the researcher accepted the $\mathrm{H} 4 \mathrm{~b}$ hypothesis.

According to the agency theory, firms with a higher level of managerial ownership would align the interests of managers and shareholders, and hence may have lower agency costs (Jensen and Meckling, 1976). Hence, a positive association is expected between managerial ownership and voluntary disclosure. However, the findings of previous research into this relationship are mixed. Nevertheless, the result is consistent with prior research (e.g., Chau and Gray, 2002; Jaing and Habib, 2009; Wang and Hussainey, 2013) who find that a positive association exists between voluntary disclosure and managerial ownership. In contrast, Eng and Mak (2003) reported a negative relationship between managerial ownership and the quality of corporate disclosures.

The study finds that the coefficient for CSRQuant on ACSZE is 1.617 and is statistically significant at $10 \%$ level of significance. This result indicates that the quantity of the CSR disclosure rises when the audit committee size increases. Therefore, the researcher accepted the H7a hypothesis that an association exists between CSR disclosure quantity and audit committee size. On the other hand, the coefficient of CSRQual on ACSZE is .015 and is not statistically significant at any level of significance. This result indicates that the CSR disclosure quality is not associated with the audit committee size. Therefore, the researcher rejects the $\mathrm{H} 7 \mathrm{~b}$ hypothesis that an association exists between the CSR disclosure quality and audit committee size. 
The agency theory suggests that firms with a good audit committee will give higher disclosure of information in order to reduce agency costs and information asymmetry. In addition, CSR disclosure is another means of mitigating the agency problem, where managers disclose more CSR information to reduce the agency costs (Barako et al. 2006) as well as to convince the external users that managers are acting in an optimal way (Watson et al., 2002). In addition, this result is also consistent with the signaling theory, which indicates that firms disclose CSR information in order to reduce the information asymmetry problem and to signal their favorable results to - investors (Oyeler et al., 2003). The results are also consistent with some previous research on voluntary disclosure. For instance, (O'Sullivan et al. 2008; Fleo et al. $2009 \mathrm{Li}$ et al. 2012) find a positive association between the disclosure of voluntary information and the audit committee.

The study finds that the coefficient for CSRQuan on REMUCOSZE is -2.494 and is statistically significant at $1 \%$ level of significance. This result indicates that the CSR disclosure quantity is negatively associated with the remuneration committee, meaning that the quantity of the CSR disclosure reduces when the size of the remuneration committee increases. Therefore, the researcher accepted the H8a hypothesis that an association exists between the CSR disclosure quantity and remuneration committee. Conversely, the coefficient of CSRQual on REMUCOSZE is -.019 and is not statically significant at any level of significance. The result shows that there is no association between the CSR disclosure quality and remuneration committee size. The H8b hypothesis is therefore rejected.

Furthermore, the coefficients of the CSR disclosure quantity (quality) on CEOD, BMET and AUDYPE are -.494 (-.002), .299 (-.003) and 1.911 (.009), respectively and they are not statistically significant at any level of significance. This result suggests that CSR disclosure (quantity or quality) are not affected by the role of CEO duality, board meetings or by auditor type. 
In terms of firm characteristics, the study finds that the coefficient for CSRQuan on SIZE is 3.351 and is statistically significant at $1 \%$ level of significance. This result indicates that a positive association exists between firm CSR disclosure quantity and firm size. In other words, the result suggests that the quantity of the CSR disclosure increases when the firm size increases. In addition, the coefficient of CSRQual on SIZE is .028 and is statistically significant at 5\% level of significance. This result indicates that a positive association exists between firm CSR disclosure quality and firm size. In other words, the result suggests that the quality of CSR disclosure increases when the firm size increases. This results is consistent with prior research (e.g., Watson et al., 2002; Boesso and Kumar, 2007; Tauringana and Mangena, 2009; Wang and Hussainey, 2013) who find that a positive relationship exists between firm size and disclosure of voluntary information.

The study finds that the coefficient for CSRQuan on LEV is -.034 and is statistically significant at $5 \%$ level of significance. This result indicates that the CSR quantity is negatively associated with firm leverage, meaning that a negative association exists between firm CSR quantity and firm leverage. In other words, the result suggests that the quantity of the CSR disclosure increases when firm leverage decreases. Furthermore, the CSRQual on LEV is .000 and is statistically significant at $1 \%$ level of significance. This result indicates that CSR disclosure quality is positively associated with firm leverage. The results are consistent with some previous research on voluntary disclosure. For instance (e.g., Tauringana and Mangena, 2009; Hussainey and Al-Najjar, 2011; Boubaker et al., 2011) find a positive association between the disclosure of voluntary information and firm leverage.

The study finds that the coefficient for CSRQuan on DIVI is -006 and is statistically significant at $1 \%$ level of significance. This result indicates that CSR quantity is negatively associated with dividends paid, suggesting that the quantity of the CSR disclosure increases when dividends paid are decreased. The result is not consistent with some previous research on voluntary disclosure. For instance, Naser et al. 2006; Wang, and Hussainey, 2012; Hussainey and Al-Najjar 2011) find a positive association between the disclosure of voluntary information and dividends paid.

Finally, the coefficients of CSR disclosure quantity (quality) on PROF and LIQ are -.060 ($.001)$ and $-.368(-.003)$, respectively, and they are not statistically significant at any level of 
significance. This result suggests that the CSR disclosure (quantity and quality) are not affected by firm profitability and firm liquidity. 
Table (4): Regression Results: Determinates of CSR disclosure quantity and quality

Panel A (DISCLOSURE QUANTITY)

Panel B ( DISCLSOURE QUALITY)

\begin{tabular}{|c|c|c|c|c|c|c|c|c|c|c|}
\hline & \multicolumn{2}{|c|}{$\begin{array}{l}\text { Unstandardised } \\
\text { Coefficients }\end{array}$} & \multirow{2}{*}{ t-Statistics } & \multirow{2}{*}{ Sig. } & \multirow{2}{*}{$\begin{array}{c}\begin{array}{c}\text { Collinearity } \\
\text { Statistics }\end{array} \\
\text { VIF }\end{array}$} & \multicolumn{2}{|c|}{$\begin{array}{c}\text { Unstandardised } \\
\text { Coefficients }\end{array}$} & \multirow{2}{*}{ t-Statistics } & \multirow{2}{*}{ Sig. } & \multirow{2}{*}{$\begin{array}{c}\begin{array}{c}\text { Collinearity } \\
\text { Statistics }\end{array} \\
\text { VIF }\end{array}$} \\
\hline & B & $\begin{array}{c}\text { Std. } \\
\text { Error }\end{array}$ & & & & B & $\begin{array}{c}\text { Std. } \\
\text { Error }\end{array}$ & & & \\
\hline Constant & $-35.848 * * *$ & 9.035 & -3.968 & .000 & & -.083 & .156 & -.536 & .593 & \\
\hline BSZE & $.826^{*}$ & .476 & 1.733 & .085 & 1.751 & $.016^{*}$ & .008 & 1.959 & .052 & 1.751 \\
\hline INDTOR & -.367 & .417 & -.881 & .380 & 1.307 & $-.015 * *$ & .007 & -2.073 & .040 & 1.307 \\
\hline GOVWN & $-16.550 * *$ & 6.558 & -2.524 & .013 & 2.335 & -.168 & .113 & -1.489 & .139 & 2.335 \\
\hline MANOWR & -1.777 & 4.981 & -.357 & .722 & 1.186 & $.233 * * *$ & .086 & 2.713 & .007 & 1.186 \\
\hline CEOD & 1.911 & 1.326 & 1.441 & .152 & 1.213 & -.002 & .023 & -.084 & .933 & 1.213 \\
\hline BMET & .299 & .290 & 1.030 & .305 & 1.358 & -.003 & .005 & -.509 & .611 & 1.358 \\
\hline ACSZE & $1.617 *$ & .893 & 1.810 & .072 & 2.062 & .015 & .015 & 1.000 & .319 & 2.062 \\
\hline REMUCOSZE & $-2.494 * * *$ & .776 & -3.216 & .002 & 2.051 & -.019 & .013 & -1.420 & .158 & 2.051 \\
\hline AUDYPE & -.494 & 1.335 & -.370 & .712 & 1.246 & .009 & .023 & .398 & .691 & 1.246 \\
\hline PROF & -.060 & .047 & -1.279 & .203 & 1.623 & -.001 & .001 & -1.539 & .126 & 1.623 \\
\hline SIZE & $3.351 * * *$ & .707 & 4.740 & .000 & 3.934 & $.028 * *$ & .012 & 2.278 & .024 & 3.934 \\
\hline LIQ & -.368 & .531 & -.692 & .490 & 1.374 & -.003 & .009 & -.327 & .744 & 1.374 \\
\hline LEV & $-.034 * *$ & .013 & -2.580 & .011 & 2.325 & $.000^{*}$ & .000 & -1.966 & .051 & 2.325 \\
\hline DIVI & $-006 * * *$ & .000 & 2.840 & .005 & 2.372 & $-008 * * *$ & .000 & 2.741 & .007 & 2.372 \\
\hline Fixed effect & \multicolumn{5}{|c|}{ Year \& Industry } & \multicolumn{5}{|c|}{ Year \& Industry } \\
\hline $\begin{array}{l}\text { Adjusted R Square } \\
\text { F -test }\end{array}$ & \multicolumn{5}{|c|}{$\begin{array}{c}.372 \\
5.800 * * *\end{array}$} & \multicolumn{5}{|c|}{$\begin{array}{c}.162 \\
2.564 * * *\end{array}$} \\
\hline F Sig. & \multicolumn{5}{|c|}{.000} & \multicolumn{5}{|c|}{.001} \\
\hline Durbin-Watson & \multicolumn{5}{|c|}{1.483} & \multicolumn{5}{|c|}{1.424} \\
\hline Observation & \multicolumn{5}{|c|}{171} & \multicolumn{5}{|c|}{171} \\
\hline
\end{tabular}

CSRQuan refers to the quantity of CSR disclosure; CSRQual is the quality of CSR disclosure; BSZE is the total number of directors on the board; INDTO number of independent directors in the firm board of directors, GOVWN is the percentage of shares owned by government, MANOW is the aggregate percentage of shares held by major shareholders (with at least $3 \%$ ownership), CEOD is a dummy variable, equals 1 if the chairman is the same person as the 
CEO of the firm, 0 otherwise BMET is the total number of board meetings during the year; ACSZE is the is the total number of directors in audit committee; REMCOSZE is the number of members of the firm's remuneration committee, AUDYPE is a dummy variable that is equal to 1 if the firm is audited by one of the largest four audit firms and 0 otherwise, PROF is firm profitability, measured using returns on the assets ratio; SIZE is the firm size, measured using the value of total assets; LIQ is firm liquidity, measured using the current ratio (current assets / current liabilities); LEV is firm leverage, measured using the ratio of total liabilities to total assets, DIVI is the total dividends paid to common shareholders.

$* * *, * *, *$ indicate significance at $.01, .05 \& .1$ level.

This table reports the Regression Results of the Determinates of CSR disclosure quantity 


\section{6- CONCLUSION}

This is the first study that empirically investigates the CSR disclosure in Saudi Arabian firms distinguishing between the quantity and quality of CSR disclosure. The study aims to measure the quantity and quality of CSR disclosure and to identify the determinants of CSR disclosure quantity and quality. It uses a sample from Saudi Arabian non-financial listed firms over the period of 2013-2014. The study develops a CSR disclosure index to measure the CSR disclosure quantity and quality.

This study finds that Saudi Arabian firms provide higher levels of CSR disclosure; however, the quality of this disclosure is low. In addition, it finds that the quantity of CSR disclosure is positively (negatively) associated with board size, (percentage of governmental ownership), size of the audit committee and (size of the remuneration committee). In contrast, the quality of the CSR disclosure is positively (negatively) associated with board size, (percentage of independent directors) and with the percentage of managerial ownership.

The results of the current study suggest important implications for users of the annual reports from Saudi Arabian non-financial firms. The research focuses on the two important themes, which are CSR disclosure quantity and quality, and the corporate governance mechanism. Clearly, there is limited literature on those two issues, particularly in developing countries (e.g., Saudi Arabia). The study develops two measures for CSR disclosure quantity and quality, which are helpful for users to evaluate the practice of CSR disclosures from Saudi Arabian firms. In addition, these measures help to enhance the reporting practices of companies concerning CSR disclosure when they present them in their annual reports. It also provides useful information to a wide range of stakeholders, particularly to those who are in developing Islamic countries.

However, the current study has some limitations, which have to be considered as potential avenues for future research. Firstly, the current study focuses on a cross sectional variation across firms ignoring the differences that may result in CSR disclosure because of the differences in the sectors. This is may be a crucial avenue for future research to analyse sectors separately. Secondly, this study focuses only on one country, which is Saudi Arabia. Future research may expand the design of the research by adding more countries to the analysis. 


\section{REFERENCES}

Abd-Elsalam, O. H., \& Weetman, P. (2003). Introducing International Accounting Standards to an emerging capital market: relative familiarity and language effect in Egypt. Journal of International Accounting, Auditing and Taxation, 12(1), 63-84.

Abdifatah, A, Haji., (2013). Corporate social responsibility disclosures over time: evidence from Malaysia. Managerial Auditing Journal, Vol. 28 No. 7, 2013 pp. 647-676.

Abdul Nasser, A. T., Wahid Abdul, E., Nazri Syed Mustapha, S. N. F., and Hudaib, M. (2006). Auditor client relationship : the case of audit tenure and auditor switching in Malaysia. Managerial Auditing Journal, 21(7), 724-737.

Abdurouf, M. (2011). The Corporate Social responsibility Disclosure: A Study of Listed Companies in Bangladesh, Business and Economics Research Journal, 2 (3), pp19-32.

Acock, A., (2008). A gentle introduction to Stata', Second edition, Stata Press, US. Advisory Committee on Improvements to Financial Reporting to SEC. (2008), 'Final Report of the Advisory Committee on Improvements to Financial Reporting to the United States Securities and Exchange Commission',pp.1-172.Available at :http://www.sec.gov/about/offices/oca/acifr/acifr-finalreport.pdf

Adams, A., (2002). Organisational factors influencing corporate social and ethical reporting. Accounting. Auditing and Accountability Journal, 15(2), 223-250.

Ahmed, K., and Nicholls, D., (1994). The impact of non-financial company characteristics on mandatory disclosure compliance in developing countries: the case of Bangladesh. The International Journal of Accounting, Vol. 29, pp. 62-77.

Albassam, W. M. (2014). Corporate governance, voluntary disclosure and financial performance: an empirical analysis of Saudi listed firms using mixed-methods of research design. PhD Thesis. University of Glasgow, United Kingdom. Available at: http://theses.gla.ac.uk/5280/

Al-Janadi, Y., Rahman, R.A., \& Omar, N.H. (2013). Corporate governance mechanisms and voluntary disclosure in Saudi Arabia. Research Journal of Finance \& Accounting, 4 (4), $25-$ 36. 
Allegrini, M. and Greco, G. (2013). Corporate Boards, Audit Committees and Voluntary Disclosure: Evidence from Italian Listed Companies. Journal of Management and Governance, 17 (1),187-216.

Al-Moataz and Hussainey, (2012). Determinants of corporate governance disclosure in Saudi companies.working paper.

Al-Moataz, E. and Lakhal, F. (2012). Corporate Governance Disclosure and Corporate Governance Mechanisms: the Case e of Saudi Listed Companies. Conference Paper, Saudi Accounting Association, Riyadh, Saudi Arabia.

Alsaeed, K. (2006). The Association between Firm-Specific Characteristics and Disclosure: The Case of Saudi Arabia. Managerial Auditing Journal, 21 (5), 476-496.

Alshehri, A., \& Solomon. J. (2012). The evolution of corporate governance in Saudi Arabia. Conference Paper, British Accounting and Finance Association (BAFA), Brighton, UK.

Aly, D., Simon, J. and Hussainey, K. (2010). Determinants of corporate internet reporting: evidence from Egypt. Managerial Auditing Journal, 25 (2), 182-202.

Anis, R.; Fraser, I. and Hussainey, K. (2012). A new measure for disclosure quality. Working paper, Stirling University, UK.

Anwar, S., Siti, H. and dan, G. (2010). Pengaruh Pengungkapan Corporate Social Responsibility terhadap Kinerja Keuangan Perusahaan dan Harga Saham. Journal. Makassar: Program Pascasarjana Universities' Hasanuddin,

Arcay, R., and Vazquez, F., (2005). Corporate Characteristics, Governance Rules and the Extent of Voluntary Disclosure in Spain. Advances in Accounting, 21, 299-331.

Arvidsson, S. (2010). communication of corporate social responsibility: A study of the views of management teams in large companies. Journal of Business Ethics, 96(3), 339-354.

ASB, (2006). Reporting Statement (RS) 1, The Operating and Financial Review. Reporting Statemen. London: ASB Publications 
Barako, D.G., Hancock, P., and Izan, H.Y. (2006). Relationship between corporate governance attributes and voluntary disclosures in annual reports: The Kenyan experience', Financial Reporting, Regulation and Governance, 5 (1), 1-25.

Barth, M. E., G. Clinch, and T. Shibano., (1999). International Accounting Harmonization and Global Equity Markets. Journal of Accounting and Economics 26, 201-235.

Beak, H.Y., Johnson, D.R. and Kim, J.W., (2009). Managerial ownership, corporate governance, and voluntary disclosure. Journal of Business and Economic Studies, 15(2), 4461.

Beest and Braam., (2013). Conceptually-Based Financial Reporting Quality Assessment. An Empirical Analysis on Quality Differences Between UK Annual Reports and US 10-K Reports. NiCE Working Paper, (November),13-106

Beest, F. V.; Braam, G. and Boelens S., (2009). Quality of Financial Reporting: measuring qualitative characteristics. Working paper, Radboud University Nijmegen.

Belal, A. and Cooper, S. (2011). The absence of corporate social responsibility reporting in Bangladesh. Critical perspectives on accounting, 1 (1), 1-14.

Boesso, G. \& K. Kumar, K., (2007). Drivers of Corporate Voluntary Disclosure: A Framework and Empirical Evidence from Italy and the United States. Accounting, Auditing and Accountability Journal, 20, 269-296.

Boesso, G. \& Kumar, K., (2007). Drivers of Corporate Voluntary Disclosure: A Framework and Empirical Evidence from Italy and the United States", Accounting, Auditing and Accountability Journal, 20: 269-296.

Bolton, P., \& Thadden, V., (1998). Blocks, liquidity, and corporate control. The Journal of Finance, 53(1), 1-25.

Botosan, C. and Plumlee, M., (2002). Are-examination of disclosure level and the expected cost of equity capital. Journal of Accounting Research, 40 (1), pp21-40.

Botosan, C., (1997). Disclosure level and the cost of equity capital. The Accounting Review, 72(3), 323-350. 
Botosan, C., (2004). Discussion of a framework for the analysis of firm risk communication. The International Journal of Accounting, 39 (3), 289-295.

Boubaker, S., Lakhal, F. and Nekhili, M., (2011). The determinants of web-based corporate reporting in France', Managerial Auditing Journal, 27 (2), 126-155.

Brammer S. and Pavelin, S., (2006). Voluntary environmental disclosures by large UK companies. Journal Business Finance Accounting, 33 (7 \& 8),1168-1188.

Brammer, S. \& Pavelin, S., (2008). Factors Influencing the Quality of Corporate Environmental Disclosure. Business Strategy and the Environment, 17(2): 120- 136.

Brennan, N.M. \& Solomon, J., (2008). Corporate Governance, Accountability and Mechanisms of Accountability: An Overview", Accounting, Auditing \& Accountability Journal, 21(7), 885-906.

Bruton, G., Fried, V., \& Hisrich, R., (1997). Venture capitalists and CEO dismissal. Entrepreneurship Theory and Practice, 21(3), 41-54.

Carroll, A. B. (1983). Corporate social responsibility: Will industry respond to cut-backs in social program funding? Vital Speeches of the Day, 49, p. 604-608.

Cerbioni, F. \& Parbonetti, A., (2007). Exploring the effects of corporate governance on intellectual capital disclosure: an analysis of European biotechnology companies. European Accounting Review, 16(4), 791-826.

Chakroun, R. \& Hussainey, K. (2014). Disclosure quality in Tunisian annual reports, Corporate Ownership and Control,11(4):58-80.

Chau, G. \& Gray, S., (2002). Ownership Structure and Corporate Voluntary Disclosure inHong Kong and Singapore. the International Journal of Accounting, 37 (1), 247265.

Chen, C.J.P., \& Jaggi, B., (2000). Association between independent nonexecutive directors, family control and financial disclosures in Hong Kong. Journal of Accounting and Public Policy, 19, 285-310.

Chen, S. Sun, Z. Tang, S. and Wu, D., (2011). Government Intervention and Investment Efficiency: Evidence from China', Journal of Corporate Finance, 17 (2), 259-271 
Cheng, C. M. E. \& Courtenay S. M., (2006). Board composition, regulatory regime and voluntary disclosure, The International Journal of Accounting, 41, 262-289.

Conyon, M. \& He, L., (2011). 'Executive Compensation and Corporate Governance in China', Journal of Corporate Finance, 17 (4), 1158-1175.

Cornett et al., (2010). Liquidity risk management and credit supply in the financial crisis. Journal of Financial Economics, 101, 297-312.

Daub, H., (2007). Assessing the Quality of Sustainability Reporting: An Alternative Methodological Approach., Journal of Cleaner Production, 15(1), 75-85.

Davidson, W.N. III, T. Pilger, \& A. Szakmary,. (1998). Golden parachutes, board and committee composition, and shareholder wealth. Financial Review 33, 17-32.

Donaldson, L., \& Davis, J. H., (1991). Stewardship theory or agency theory: CEO governance and shareholder returns. Australian Journal of management, 16(1), 49-64.

Eisenhardt, K., (1989). Agency theory: An assessment and review. Academy of Management Review, 14(1), 57-74.

Elshandidy, T. Fraser, I., \& Hussainey, K., (2013). Aggregated, voluntary, and mandatory risk disclosure incentives: Evidence from UK FTSE all-share companies. International Review of Financial Analysis, 30, 320-333.

Elzahar, H. \& Hussainey, K., (2012). Determinants of narrative risk disclosures in UK interim reports. The Journal of Risk Finance. 13 (2), 133-147

Elzahar, H., (2013). Determinants and Consequences of Key Performance Indicator (KPI) Reporting by UK Non-financial Firms, PhD thesis, University of Stirling, UK.

Eng, L.L. \& Mak, Y.T., (2003). 'Corporate governance and voluntary disclosure', Journal of Accounting and Public Policy, 22, 325-345.

European Commission,. (2002). The Corporate Social Responsibility: A Business Contribution to Sustainable Development (Office of the Official Publications of the European Communities ,Luxembourg), (online), the European commission website, available at 
http://ew.eea.europa.eu/industry/Reporting/cec_corporate_responsibility/com200 _036en01.pdf.

Ezzamel, M., \& Watson, R., (1997). Wearing two hats: the conflicting control and management roles of non -executive directors. Corporate governance, 54-79.

Fama, E.F. \& Jensen, M.C., (1983). 'Separation of ownership and control', Journal of Law and Economics, 26 (2), 301-326.

Felo, A.J., Krishnamurthy, S. \& Solieri, S.A., (2009). Are all audit committee financial experts created equally? International Journal of Disclosure and Governance, 6(2), 150-166.

Field, A., (2009). Discovering statistics using SPSS. London: Sage.

Financial Accounting Standards Board (FASB), (1974). Statement of financial accounting standard no. 2: Accounting for research and development costs.

Financial Reporting Council,( FRC),. (2008). The UK Corporate Governance Code. UK.

Financial Reporting Council., (2009). A Review of Narrative Reporting by UK Listed Companies in 2008/2009', pp.1-45.Available at: http://www.frc.org.uk/images/uploaded/documents/Full\%20results\%20of\%20a\%20Review\% 2 of\%20narrative\%20reporting1.pdf

Forker, J.J., (1992). Corporate governance and disclosure quality. Accounting and Business Research 22 (86), 111-124.

Freeman, R., (1984). Strategic Management : A Stakeholder Approach, Pitman, Boston, MA. Galbreath, J., (2010). Drivers of corporate social responsibility: the role of formal strategic planning and firm culture. British Journal of Management, 21(2), 511-525.

Golob, U. \& Bartlett, J., (2007). Communicating about corporate social responsibility: A comparative study of CSR reporting in Australia and Slovenia. Public Relations Review, 33, $1-9$.

Gray R. Owen, D. \& Adams, M., (1996). Accounting and accountability: Social and environmental accounting in a changing world, London, (Hemel Hempstead: Prentice Hall). 
GRI (2009b). The GRI guidelines: An executive summary, available on the internet at: www.globalreporting.org/NR/rdonlyres/CF868D62-21F2 40DF-B090-

Gujarati, DN and DC Porter. (2009). Basic Econometrics, 5th edition, New York: McGrawHill.

Gul, A., \& Leung, S., (2004). Board leadership, outside directors' expertise and voluntary corporate disclosures. Journal of Accounting and Public Policy, 23(5), 351-379.

Guthrie, J., \& Parker, L. D., (1989). Corporate social reporting: a rebuttal of legitimacy theory. Accounting and business research, 19(76), 343-352.

Guthrie, J., \& Parker, L., (1989). Organizational social reporting: A rebuttal of legitimacy theory', Accounting and Business Research, 19 (76), 343-352.

Habbash, M. at. al., (2015). the determinants of voluntary disclosure in Saudi Arabia: an empirical study. Working paper.

Hackston, D \& Milne J., (1996). Some determinants of social and environmental disclosure in New Zealand companies. Accounting, Auditing and Accountability Journal, 18 (1), 77-108.

Hail, L., (2002). The impact of voluntary corporate disclosures on the ex-ante cost of capital for Swiss firms. Available at SSRN 279276.

Halme, M., \& Huse, M., (1997). The influence of corporate governance, industry and country factors on environmental reporting. Scandinavian Journal of Management, 13(2), 137-157.

Haniffa, R. \& Cooke, T., (2002). Culture, corporate governance and disclosure in Malaysian corporations. Abacus, 38(3), 317-349.

Hassan, O. \& Marston, C., (2010). Disclosure measurement in the empirical accounting literature: a review article', working paper, Economics and Finance', Working Paper Series, Brunel University, available at: http://www.brunel.ac.uk/about/acad/sss/depts/economics

Hassanein, A., \& Hussainey, K., (2015). "Is forward-looking financial disclosure really informative? Evidence from UK narrative statements". International Review of Financial Analysis, 41, 52-61. 
Healy, P. \& Palepu, K., (2001). Information asymmetry, corporate disclosure practice, and the capital markets: a review of empirical literature. Journal of Accounting and Economics, $31,405-440$.

Ho, C.A. \& Williams, S.M., (2003). International Comparative Analysis of the Association between Board Structure and the efficiency of Value Added by a Firm from its Physical Capital and Intellectual Capital Resources, The International Journal of Accounting, 38 (4), 465-491.

Ho, S., \& Wong, K., (2001). A study of the relationship between corporate governance structures and the extent of voluntary disclosure", Journal of International Accounting, Auditing and Taxation, 10(2), 139-156.

Hoitash, U., Hoitash, R. \& Bedard, J.C., (2009). Corporate governance and internal control over financial reporting: a comparison of regulatory regimes. The Accounting Review, 84(3), 839-867.

Hooghiemstra, R., (2000). Corporate Communication and Impression Management. New Perspectives Why Companies Engage in Corporate Social Reporting”, Journal of Business Ethics, 27: 55-68.

Hope, O., (2003). Firm-level disclosures and the relative roles of culture and legal origin. Journal of International Financial Management and Accounting, 14 (3), 218-48.

Hossain, M. Perera, M. \& Rahman, A., (1995). Voluntary disclosure in the annual reports of New Zealand Companies. Journal of International Financial Management and Accounting, 6 (1), 69-87.

Hussainey, K. \& Al-Najjar, B., (2011). Future-oriented narrative reporting: determinants and use. Journal of Applied Accounting Research, 12(2), 123-138.

Hussainey, K. \& Al-Nodel, A., (2008). Corporate governance online reporting by Saudi listed companies", Research in Accounting in Emerging Economics, 8, 39-64.

Hussainey, K., Mgbame, C. O., \& Chijoke-Mgbame, A. M., (2011). Dividend policy and share price volatility: UK evidence. The Journal of Risk Finance, 12, 57-68. 
IASB (2010), 'Management Commentary: A framework for presentation', International Accounting Standard Board, London.

IFRS (2010a). Practice statement, MC, A framework for presentation. International Financial Reporting Standard, London: UK.

International Accounting Standards Board (IASB), (2008). Exposure Draft on an improved Conceptual Framework for Financial Reporting: The Objective of Financial Reporting and Qualitative Characteristics of Decision-useful Financial Reporting Information. London

ISO 9001., (2008). Sets out the criteria for a quality management system and is the only standard in the family that can be certified to (although this is not a requirement).

Jensen, M. \& Meckling, W., (1976). Theory of the firm: management behaviour, agency costs and ownership structure. Journal of Financial Economics, 3(3), 305-360.

Jensen, M., (1993). The modern industrial revolution, exit and the failure of internal control systems, The Journal of Finance, 48 (3), 831-80.

Jiang, H. \& Habib, A., (2009). The impact of ownership concentration on voluntary disclosure practices in New Zealand', Accounting Research Journal, 22, (3), 275-304.

Jonas, G. J., \& Blanchet, J., (2000). Assessing quality of financial reporting. Accounting Horizons, 14(3), 353-363.

Karamanou, I., \& Vafeas, N., (2005). The association between corporate boards, audit committees, and management earnings forecasts: An empirical analysis. Journal of Accounting research, 43(3), 453-486.

Konijn, S.J.J., Kräussl, R. \& Lucas, A., (2011). Blockholder dispersion and firm value. Journal of Corporate Finance, 17(5), 1330-1339.

Krause, R. Semadeni, M. \& Cannella, A., (2014). CEO Duality A Review and Research Agenda. Journal of Management, 40, (1), 256-286.

Lakhal, F., (2005). Voluntary earnings disclosures and corporate governance: Evidence from France. Review of Accounting and Finance, 4(3), 64-85. 
Laksmana, I., (2008). Corporate Board Governance and Voluntary Disclosure of Executive Compensation Practices .Contemporary Accounting Research, 25, (4), 1147-1182.

Lev, B. \& Penman, S., (1990). Voluntary Forecast Disclosure, Non-Disclosure and Stock Prices. Journal of Accounting Research, 1, (1), 49-76.

Li, J., Mangena, M. \& Pike, R., (2012). The effect of audit committee characteristics on intellectual capital disclosure. The British Accounting Review, 44, 98-110

Li, J., Pike, R. \& Haniffa, R., (2008). Intellectual capital disclosure and corporate governance structure in UK firms. Accounting and Business Research, 38(2), 137-159.

Linsley, P. M., \& Shrives, P. J., (2006). Risk reporting: A study of risk disclosures in the annual reports of UK companies. The British Accounting Review, 38(4), 387-404.

Lipton, M., \& Lorsch, J. W., (1992). A modest proposal for improved corporate governance. The business lawyer, 59-77.

Luo, X., \& Bhattacharya, C. B., (2006). Corporate social responsibility, customer satisfaction, and market value. Journal of marketing, 70(4), 1-18.

Makhija, A. K., \& Patton, J. M., (2004). The Impact of Firm Ownership Structure on Voluntary Disclosure: Empirical Evidence from Czech Annual Reports. The Journal of Business, 77(3), 457-491.

Mashayekhi, B. \& Bazaz, M., (2008). Corporate Governance and Firm Performance in Iran’, Journal of Contemporary Accounting and Economics, 4, (2), 156-172.

McWilliams, A., \& Siegel, D., (2001). Corporate social responsibility: A theory of the firm perspective. Academy of management review, 26(1), 117-127.

McWilliams, A., Siegel, D., \& Wright, P., (2006). Corporate social responsibility: Strategic implications. Journal of management studies, 43(1), 1-18.

Morris, R., (1987). Signalling, agency theory and accounting policy choice. Accounting and Business Research, 18, (69), 47-56. 
Nelson, J., Gallery, G., \& Percy, M., (2010). Role of corporate governance in mitigating the selective disclosure of executive stock option information', Accounting \& Finance, 50, (3), 685-717.

Newson, M \& Deegan, C., (2002). Global expectations and their associations with corporate social disclosure practice in Australia, Singapore and South Korea. The International Journal of Accounting, 37, 183-213.

Nicholson, G. J., \& Kiel, G. C., (2007). Can Directors Impact Performance? A case based test of three theories of corporate governance. Corporate Governance: An International Review, 15(4), 585-608.

Ntim, C. Opong, K. Danbolt, J. \& Thomas, D., (2012a). Voluntary Corporate Governance Disclosures by Post-Apartheid South African Corporations', Journal of Applied Accounting Research, 13, (2), 122-144.

O’Sullivan, M., Percy, M. \& Stewart. J., (2008). Australian evidence on corporate governance attributes and their association with forward looking information in the annual report. Journal of Management and Governance, 12(1), 5-35.

Oyeler, P., Laswad, F. \& Fisher, R., (2003). Determinants of internet financial reporting by New Zealand companies. Journal of International Management and Accounting, Vol. 14 No. 1, pp. 26-63.

Raffournier, B., (1995). The determinants of voluntary financial disclosure by Swiss listed companies; European Accounting Review, 1995, 4, (2), 261-280.

Report on the Observance of Standards and Codes (ROSC)., (2009). A Corporate Governance Country Assessment for The Arab Republic of Egypt; http://www.worldbank.org/ifa/rosc_cg_egy.pdf

Rose, J.M., (2007). Corporate Directors and Social Responsibility: Ethics Versus Shareholder Value", Journal of Business Ethics, 73: 319-333.

Samaha, K., \& Dahawy, K., (2011). An empirical analysis of corporate governance structures and voluntary corporate disclosure in volatile capital markets: the Egyptian 
experience", International Journal of Accounting, Auditing, and Performance Evaluation (IJAAPE), 7, (1-2), 61-93.

Saudi Arabian General Investment Authority (SAGIA), available at http://www.sagia.gov.sa/en/Why-Saudi-Arabia/

Schiehll, E. Terra, P. \& Victor, F., (2013). Determinants of Voluntary Executive Stock Option Disclosure in Brazil', Journal of Management and Governance, 19, (4), 333-343.

Schleicher, T. \& Walker, M., (2010). Bias in the tone of forward-looking narratives. Accounting and Business Research, 40 (4), 371-390.

Shleifer, A., (1998). State versus private ownership: National bureau of economic research.

Siebels, J. \& Knyphausen-Aufseb, D., (2012). A Review of Theory in Family Business Research: The Implications for Corporate Governance', International Journal of Management Reviews, 14, ( 3), 280-304.

Simon, S., Saeed. H. \& Zezheng, X., (2005). Determinants of corporate social and environmental reporting in Hong Kong: a research note', Accounting Forum, 29 (1), 233-242.

Sun, N; Salama, A; Hussainey, K; \& Habbash, M., (2010). Corporate environmental disclosure, corporate governance and earnings management; Managerial Auditing Journal, 25, (7), 679-700.

Tabachnick, B. \& Fidell, L., (2007). Using multivariate statistics', fifth edition, Pearson Education, Inc., London.

Tauringana, V. \& Mangena, M., (2009). Association between reportable segments and key performance indicators disclosure', British Accounting Association (BAA) Annual Conference, Dundee, Scotland, April the Saudi Organization for Certified Public Accountants (SOCPA). (2012). Available at: http://www.socpa.org.sa/Home/Homepage?lang=en, Accessed on 24/4/ 2014.

The Saudi Stock Exchange (Tadawul)., (2012). Available at: http://www.Tadawul.com.sa, 
Wallace, R. Nasser, K. \& Mora, A., (1994). The relationship between the comprehensive of corporate annual reports and firm characteristics in Spain", Accounting \& Business Research, $25,(97), 41-53$.

Wang, M. \& Hussainey, K., (2013). Voluntary forward-looking statements driven by corporate governance and their value relevance', Journal of Accounting and Public Policy, 32, (3), 26-49.

Xiao, J. Yang, H. \& Chow, C., (2004). The determinants and characteristics of voluntary internet based disclosures by listed Chinese companies", Journal of Accounting \& Public Policy, 23, ( 3), 191-225. 


\section{Appendix1: CSR disclosure quantity index}

\begin{tabular}{|c|c|}
\hline 1. Employee & 5. Environmental Issues \\
\hline Employee Data & Environmental policy statement \\
\hline Training \&Development & 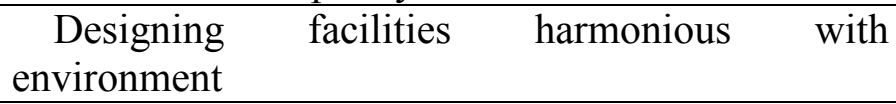 \\
\hline Employees Benefit & Using recycling material \\
\hline Pension & Sponsoring environmental activities \\
\hline Work place & pollution \\
\hline 2. Community & Waste management \\
\hline Community investment & Conservation of natural resources \\
\hline Contribution to national economy & 6. Energy \\
\hline Education & Disclosing the company energy policies \\
\hline Health and safety & Conservation of energy \\
\hline Social Loan & $\begin{array}{l}\text { Disclosing increased energy efficiency of } \\
\text { products }\end{array}$ \\
\hline Social activities support & $\begin{array}{l}\text { 7. Other Disclosures regarding to Saudi } \\
\text { environment }\end{array}$ \\
\hline Funding scholarship programs & $\begin{array}{l}\text { Charitable society for the holy Quran memorization } \\
\text { holly }\end{array}$ \\
\hline Human rights & Ongoing charity ( WAGFF) \\
\hline Charity \& Donation & Hajj donations \\
\hline volunteering & Others disclosure related to Sharia activities \\
\hline \multicolumn{2}{|l|}{ Establish non-profit project } \\
\hline \multicolumn{2}{|l|}{ 3. Products and Services } \\
\hline \multicolumn{2}{|l|}{ Developing \& innovating new products } \\
\hline \multicolumn{2}{|l|}{ Products \& services quality } \\
\hline \multicolumn{2}{|l|}{ ISO \& other awards } \\
\hline \multicolumn{2}{|l|}{ Guidance campaigns } \\
\hline \multicolumn{2}{|l|}{ 4. Customer } \\
\hline \multicolumn{2}{|l|}{ Information of commercial and marketing } \\
\hline \multicolumn{2}{|l|}{ Meeting customer needs } \\
\hline \multicolumn{2}{|l|}{ customer feedback } \\
\hline \multicolumn{2}{|l|}{ Customer service } \\
\hline \multicolumn{2}{|l|}{ Customer satisfaction } \\
\hline Existing of certificated systems of quality & \\
\hline
\end{tabular}


Appendix 2: The index to measure of CSR disclosure quality index

\begin{tabular}{|c|c|c|c|}
\hline \multicolumn{4}{|l|}{ Relevance } \\
\hline Question no & Question & Likert's & Literature \\
\hline R1 & $\begin{array}{l}\text { To what extent does the } \\
\text { company disclosed the } \\
\text { CSR in the annual } \\
\text { report? }\end{array}$ & $\begin{array}{l}\text { 1= No disclose about CSR } \\
2-\text { Disclosed of CSR information } \\
\text { limited (boilerplate paragraph). } \\
3=\text { Disclosed for Forward-looking } \\
\text { information. } \\
4=\text { Apart subsection of CSR. } \\
5=\text { Extensive information useful for } \\
\text { making expectation. }\end{array}$ & $\begin{array}{l}\text { e.g. McDaniel et } \\
\text { al., 2002; Jonas and } \\
\text { Blanchet, 2000; } \\
\text { Beest et al. } 2009 \\
\text { Chakroun and } \\
\text { Hussainey, } 2014\end{array}$ \\
\hline R2 & $\begin{array}{l}\text { To what extent does the } \\
\text { presence of non- } \\
\text { financial company in } \\
\text { terms of business } \\
\text { opportunities and to } \\
\text { what extent contribute to } \\
\text { the society and } \\
\text { environment? }\end{array}$ & $\begin{array}{l}1 \text { = No non-financial information } \\
2=\text { Little non-financial information, } \\
\text { no useful for forming expectations } \\
3=\text { Useful non-financial information } \\
4=\text { Useful financial information, } \\
\text { helpful for developing expectations } \\
5=\text { Non-financial information } \\
\text { presents additional information } \\
\text { which helps developing expectations }\end{array}$ & $\begin{array}{l}\text { e.g. Jonas and } \\
\text { Blanchet, } 2000 \\
\text { Chakroun and } \\
\text { Hussainey, 2014; } \\
\text { Beest et al. } 2009\end{array}$ \\
\hline \multicolumn{4}{|c|}{ Faithful representation } \\
\hline F1 & $\begin{array}{l}\text { To what extent does the } \\
\text { company, in the } \\
\text { discussion of CSR in the } \\
\text { annual report, highlight } \\
\text { the positive events as } \\
\text { well as the negative } \\
\text { events? }\end{array}$ & $\begin{array}{l}1=\text { No positive } \& \text { negative events, } \\
\text { are mentioned } \\
2=\text { Negative events only mentioned } \\
\text { in footnotes } \\
3=\text { Emphasize on positive events } \\
4=\text { Balance positive/negative events } \\
\text { of CSR } \\
5=\text { Impact of positive/negative } \\
\text { events of CSR is also explained }\end{array}$ & $\begin{array}{l}\text { e.g. Razaee, 2003; } \\
\text { Cohen et al., } 2004 \\
\text { Chakroun and } \\
\text { Hussainey, 2014; } \\
\text { Beest et al. } 2009\end{array}$ \\
\hline $\mathrm{F} 2$ & $\begin{array}{l}\text { To what extent does the } \\
\text { company provide more } \\
\text { explain of CSR } \\
\text { information? }\end{array}$ & $\begin{array}{l}1=\text { No description of CSR } \\
2=\text { Information on CSR limited, } \\
3=\text { Apart subsection of CSR } \\
4=\text { Extra attention paid to } \\
\text { information concerning CSR } \\
5=\text { Comprehensive description of } \\
\text { CSR }\end{array}$ & $\begin{array}{lr}\text { e.g. Jonas } & \text { and } \\
\text { Blanchet, } & 2000 ; \\
\text { Chakroun } & \text { and } \\
\text { Hussainey, 2014; } & \text { Beest et al. } 2009\end{array}$ \\
\hline \multicolumn{4}{|c|}{ Understandability } \\
\hline U1 & $\begin{array}{l}\text { To what extent is the } \\
\text { annual report presented } \\
\text { of CSR in a well- } \\
\text { organized manner? }\end{array}$ & $\begin{array}{l}1=\text { Very bad presentation ( no text } \\
\text { of CSR) } \\
2=\text { Bad presentation ( text only) } \\
3 \text { = Poor presentation (text and } \\
\text { graphs ) } \\
4=\text { Good presentation ( text, graphs } \\
\text { and ratio ) } \\
5=\text { Very good presentation ( full } \\
\text { paragraph with more descriptive ) }\end{array}$ & $\begin{array}{l}\text { e.g. Jonas and } \\
\text { Blanchet, } 2000 \\
\text { Chakroun and } \\
\text { Hussainey, 2014; } \\
\text { Beest et al. } 2009\end{array}$ \\
\hline
\end{tabular}




\begin{tabular}{|c|c|c|c|}
\hline $\mathrm{U} 2$ & $\begin{array}{l}\text { To what extent does the } \\
\text { presence of graphs and } \\
\text { tables clarifies the } \\
\text { presented information of } \\
\text { CSR? }\end{array}$ & $\begin{array}{l}1=\text { No graphs } \\
2=1-5 \text { graphs } \\
3=6-10 \text { graphs } \\
4=11-15 \text { graphs } \\
5=>15\end{array}$ & $\begin{array}{l}\text { e.g. Jonas and } \\
\text { Blanchet, 2000; } \\
\text { Beest et al. 2009; } \\
\text { Chakroun and } \\
\text { Hussainey, 2014 }\end{array}$ \\
\hline \multicolumn{4}{|c|}{ Comparability } \\
\hline $\mathrm{C} 1$ & $\begin{array}{l}\text { To what extent is the } \\
\text { information of CSR in } \\
\text { the annual report } \\
\text { comparable to } \\
\text { information provided by } \\
\text { other organizations? }\end{array}$ & $\begin{array}{l}1=\text { No comparability ( no } \\
\text { paragraph) } \\
2=\text { Limited comparability ( one } \\
\text { paragraph) } \\
3=\text { Moderate comparability (two } \\
\text { paragraph) } \\
4=\text { Very much comparability (two } \\
\text { paragraph with numbering) } \\
5=\text { Very extensive comparability } \\
\text { ( more than above) }\end{array}$ & $\begin{array}{lr}\text { e.g. IASB, 2008; } \\
\text { Jonas and } \\
\text { Blanchet, 2000. } \\
\text { Chakroun and } \\
\text { Hussainey, 2014; } \\
\text { Beest et al. } 2009\end{array}$ \\
\hline $\mathrm{C} 2$ & $\begin{array}{l}\text { To what extent does the } \\
\text { company presents } \\
\text { financial index numbers } \\
\text { of CSR and ratios in the } \\
\text { annual report? }\end{array}$ & $\begin{array}{l}1=\text { No ratios } \\
2=1-2 \text { ratios } \\
3=3-5 \text { ratios } \\
4=6-10 \text { ratios } \\
5=>10 \text { ratios }\end{array}$ & $\begin{array}{lr}\text { e.g. Cleary, } & 1999 ; \\
\text { Chakroun and } \\
\text { Hussainey, 2014; } \\
\text { Beest et al. } 2009\end{array}$ \\
\hline
\end{tabular}

\section{Relevance}

Information is considered to be relevant when it has a high ability of making difference in many of the decisions taken by users "(. IASB, 2010, p. 17). IFRS progress that "Financial information is able to make a difference in decision-making.

\section{Faithful representation}

For information to be faithfully representative, it should be complete, natural, and free of material misstatement (IASB, 2010).

\section{Understandability}

The IASB (2010) define the understandability as understanding of knowledge regarding the quality of the information which enabled users to understand their meaning. IASB (2010) suggest that understandability is enhanced when information is classified, characterized and presented clearly and concisely.

\section{Comparability}

The Comparability is considered to be the quality of information that enables users to identify similarities in, and differences between, two sets of economic phenomena characteristic 
(IASB, 2010). In addition, it helps users to identify the key trends and analyse the performance of the company over time (ASB, 2006). 